\title{
$+X+$. Un progetto di eco-costruzioni ludiche per insegnare i principi dell'architettura modulare
}

Giovanni Caffio

Abstract

Questo articolo presenta un'esperienza multidisciplinare realizzata per il Dipartimento di Architettura di Pescara in occasione della Notte dei Ricercatori 2019 (tenutasi a Chieti nella giornata del 27 settembre 2019) in cui disegno, progetto, allestimento, comunicazione istituzionale e attività ludica si uniscono e collaborano per far awicinare un pubblico eterogeneo, e in particolare i bambini in età scolare e prescolare, al mondo della ricerca e della didattica dell'architettura. II progetto e la realizzazione del padiglione temporaneo e delle attività ludiche basate sul gioco di eco-costruzioni progettato per l'occasione hanno permesso di evidenziare elementi utili ad avvalorare l'utilità del gioco delle costruzioni per il miglioramento delle capacità di visualizzazione e spazializzazione, di problem solving e di cooperazione in chiave inclusiva.

Parole chiave

didattica, disegno, gioco, costruzioni, installazione.

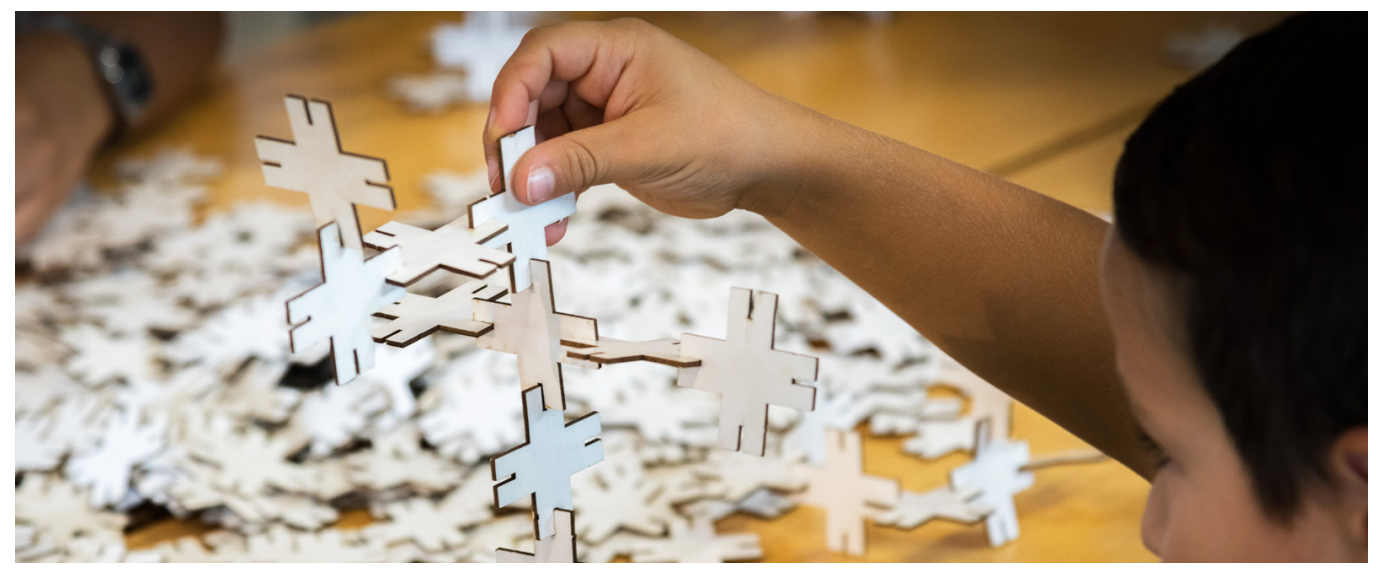




\section{Introduzione}

Questo saggio descrive e analizza un'esperienza progettuale e ludica del Dipartimento di Architettura di Pescara svolta in occasione della Notte dei Ricercatori 2019 che si è svolta a Chieti nella giornata del 27 settembre 2019. L'esperienza nasce dall'esigenza di comunicare in modo semplice e diretto le attività e la mission del Dipartimento di Architettura a un pubblico costituito in larga parte da famiglie e bambini.

La Notte dei Ricercatori è un'iniziativa supportata dalla Commissione Europea che, a partire dal 2015, si svolge ogni anno attivando migliaia di ricercatori e centri di ricerca in tutti i paesi europei. Si tratta di un'importante occasione in cui ricercatori universitari e cittadini comuni si incontrano e dialogano col fine di espandere la cultura scientifica e permettere di comprendere l'impegno e il valore delle professioni scientifiche all'interno di cornici non formali e inclusive. Fin dal primo inizio l'Italia ha aderito all'iniziativa divenendone uno dei paesi con il maggior numero di manifestazioni sparse per tutto il territorio nazionale. Nel 2019 il progetto ha coinvolto I I progetti per un totale di I I 6 città tra cui Chieti e Pescara. Nel 20 I 8 l'evento della Notte dei Ricercatori si è svolta in due giornate: la prima a Pescara e la seconda per le vie del centro di Chieti dove sono stati organizzati stand e padiglioni legati all'orientamento e alla descrizione dei diversi corsi di laurea, conferenze divulgative e spettacoli, dimostrazioni scientifiche dal vivo, visite guidate a mostre ed esposizioni, ma soprattutto sono stati allestite numerose attività ludico-educative che hanno permesso di intrattenere informando grandi numeri di studenti provenienti soprattutto dalle scuole primarie.

Sulla base dell'esperienza dell'anno precedente, nel 2019 il gruppo incaricato alla progettazione e realizzazione dell'evento (diretto dal direttore del Dipartimento Paolo Fusero e coordinato da chi scrive e a cui hanno collaborato dottorandi e studenti di diversi corsi di laurea, nonché coadiuvati dal personale tecnico amministrativo) ha pensato di strutturare lo spazio messo a disposizione del Dipartimento come un luogo di sperimentazione e di gioco in cui, più che illustrare i risultati delle ricerche e della didattica in corso, si desse spazio alla sperimentazione dei principi base della progettazione architettonica, un'attività ludica che mostrasse attraverso l'azione libera e creativa, i presupposti metodologici che sono alla base

Figg. I, 2. Progetto delle tessere modulari e loro possibilità di incastro. Manifesto dell'evento con alcune possibili aggregazioni.
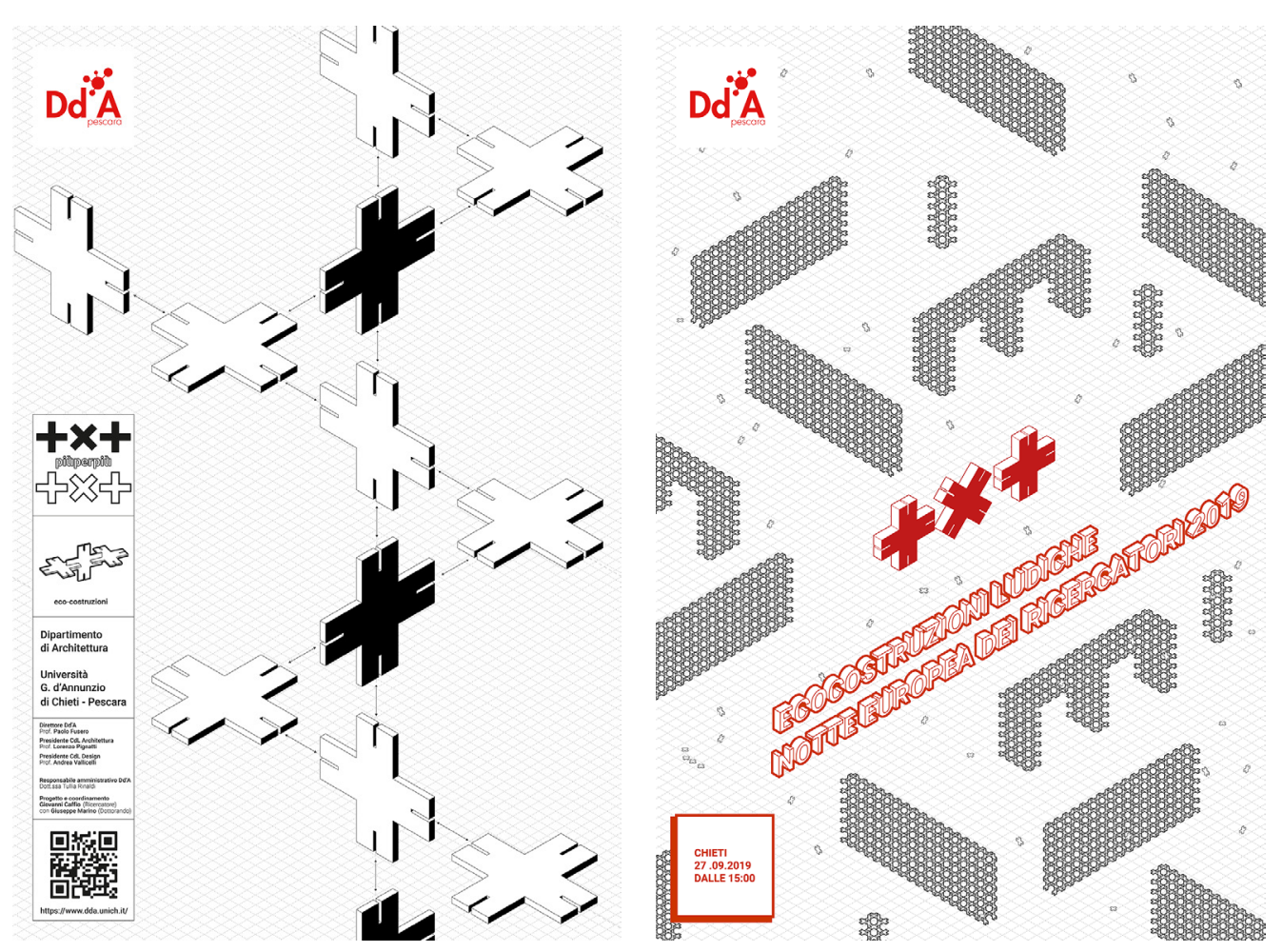
del percorso creativo sperimentato in tutte le discipline che collaborano alla formazione dell'architetto. La scelta, pertanto, non si è focalizzata su specifici risultati o metodologie quanto sulla sperimentazione concreta di azioni costruttive e compositive fondamentali, un modo per far avvicinare, in maniera concreta e giocosa, un pubblico, soprattutto di giovane età, ai principi dell'architettura. Date queste premesse, dopo aver vagliato varie ipotesi, la decisione è caduta sull'idea di lavorare sul gioco delle costruzioni, sicuramente una delle attività più amate nell'infanzia ma che non sempre trova spazio come strumento didattico nella scuola primaria e nella scuola secondaria di primo e secondo grado nonostante le sue elevate capacità per quanto riguarda il campo dell'apprendimento. Questa attività ludica, infatti, si basa su azioni concrete e manipolabili, incoraggia processi di apprendimento e ragionamento basati sul principio del learning by doing e consente ai suoi utilizzatori di mettere letteralmente in gioco abilità di tipo superiore secondo atteggiamenti ludici e creativi.

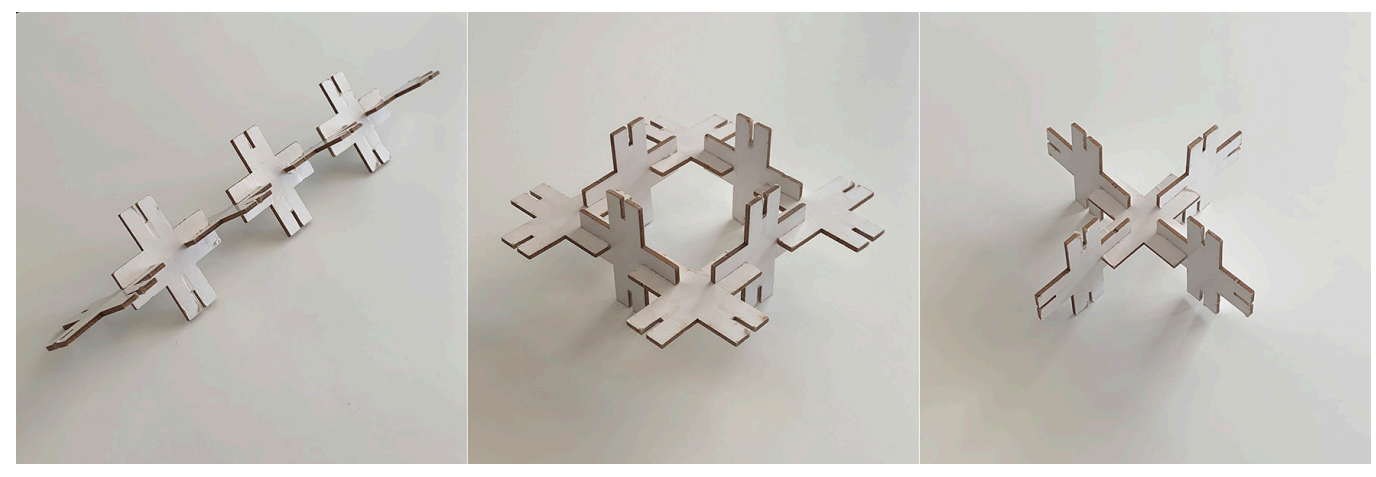

\section{II progetto}

Il primo passo è consistito in una ricerca per analizzare i giochi di costruzioni presenti sul mercato sulla base di esperienze laboratoriali pubbliche recenti come quelle condotte da Winy Maas e Olafur Eliason. II primo, nel novembre 20 I 8, ha realizzato un interessante laboratorio dal titolo Milano Futura in cui ha coinvolto 38 studenti del terzo anno di una scuola secondaria di primo grado di Milano. L'obiettivo è stato re-immaginare la città a partire dal proprio quartiere usando come materiale i mattoncini Lego [Maas 2019].

Olafur Eliasson, invece, ha realizzato un grande spazio per la creazione di costruzioni all'interno della propria mostra che si è tenuta alla Tate Modern a Londra dal 28 luglio al I 8 agosto 2019. I visitatori hanno potuto usare migliaia di mattoncini bianchi per realizzare modelli che nell'insieme rappresentano una visione collettiva e in progress di città futura. Un'opera collettiva realizzata smontando, connettendo e ricostruendo gli elementi lasciati da ogni partecipante. Questo lavoro, dal titolo The cubic structural evolution project, è stato presentato per la prima volta nel 2004 al Queensland Art Gallery \& Gallery of Modern Art utilizzando mattoncini Lego privi di marchio e senza istruzioni.

La ricerca sul mercato ha evidenziato come nella grande maggioranza dei giochi commerciali il materiale più utilizzato sia proprio la plastica, cosa che crea non pochi problemi di gestione e smaltimento di questi giocattoli. Inoltre, il materiale plastico anche se più resistente e versatile quanto a forme, colori e modelli, non presenta quelle caratteristiche tattili e sensoriali che invece caratterizzano i materiali naturali. Poiché il tema della Notte dei Ricercatori 2019 era quello della sostenibilità, sono stati scartati i mattoncini più noti e abbiamo focalizzato l'attenzione su alternative naturali, come le costruzioni in legno tipo Kapla che, seppure più coerenti con il tema della sostenibilità e con le caratteristiche tattili dei giochi più evoluti, non si prestano a tipologie di costruzioni articolate e sofisticate, rimanendo soprattutto confinate a una fascia di età molto bassa. Per questo motivo abbiamo deciso di progettare e realizzare un sistema di costruzioni ludiche che soddisfacesse le nostre richieste di partenza, 
ovvero essere realizzato in materiale naturale, riciclabile e sostenibile, nonché essere in grado di creare aggregazioni modulari di una sufficiente complessità.

II punto di partenza per questo progetto è stato lo studio dei sistemi grafico-modulari come quelli studiati nel campo della rappresentazione da studiosi quali Bruno Munari (1972), Attilio Marcolli (1978) e Franco Mirri (1992). Per la progettazione del modulo base è stata scelta una forma geometrica semplice da gestire in fase di produzione, flessibile e che offrisse un numero sufficiente di possibilità di aggregazione: la figura geometrica piana del quadrato. II tipo di incastro, anche questo molto semplice, è del tipo 'a mezzo legno'. In questo incastro sui lati del quadrato sono realizzate quattro fessure che hanno la larghezza pari allo spessore della tessera e la profondità pari I/4 del lato del quadrato. In questo tipo di giunzione, due tessere si incastrano ruotando l'una rispetto all'altra di 90 gradi. II passo successivo è consistito nel modificare il quadrato di base per ridurre la quantità di materiale da lavorare lasciando intatta la solidità degli incastri. Dopo diversi tentativi la scelta è caduta su un disegno a croce greca in cui i lati corti sono esattamente 1/3 del lato del quadrato di base e la profondità degli incavi è stata ridotta a 1/6 del quadrato di base (figg. I, 2).

Questo tipo di incastro permette combinazioni base che possono essere a sviluppo lineare, a base quadrata con 5 moduli e a base quadrata con 8 moduli e tutte le infinite combinazioni che nascono dalla aggregazione di queste forme base (fig. 3).

Di questo sistema modulare è stato deciso di produrre due versioni: la prima, finalizzata al gioco delle costruzioni per $\mathrm{i}$ bambini, ha una dimensione di $5 \times 5 \mathrm{~cm}$ ed è realizzata in cartone pressato e rivestito di cartoncino bianco poi tagliato con plotter a laser; la seconda, pensata per realizzare parte del padiglione espositivo, adotta tessere $30 \times 30 \mathrm{~cm}$ in cartone ondulato dello spessore di $4 \mathrm{~mm}$ fustellato (fig. 4).

Le tessere per il gioco sono state realizzate in un numero di 9300 pezzi (dei quali 4200 usati per il gioco libero e 5100 usati per dei kit di gioco che sono stati regalati come gadget ai piccoli partecipanti) (fig. 5) mentre quelle per la costruzione dell'installazione sono state prodotte in numero di 4200 pezzi.

Queste eco-costruzioni, $+x+$ il nome che è stato dato loro, rappresentano una tecnologia low cost ma efficace e, nonostante non posseggano la 'indistruttibilità' dei mattoncini di plastica, hanno in sé il senso di una durata limitata, propria delle risorse naturali. In questo senso, il loro uso e il loro graduale deperimento rinforza l'idea di un uso consapevole e sostenibile delle materie prime. Un messaggio ecologista implicito e concreto.
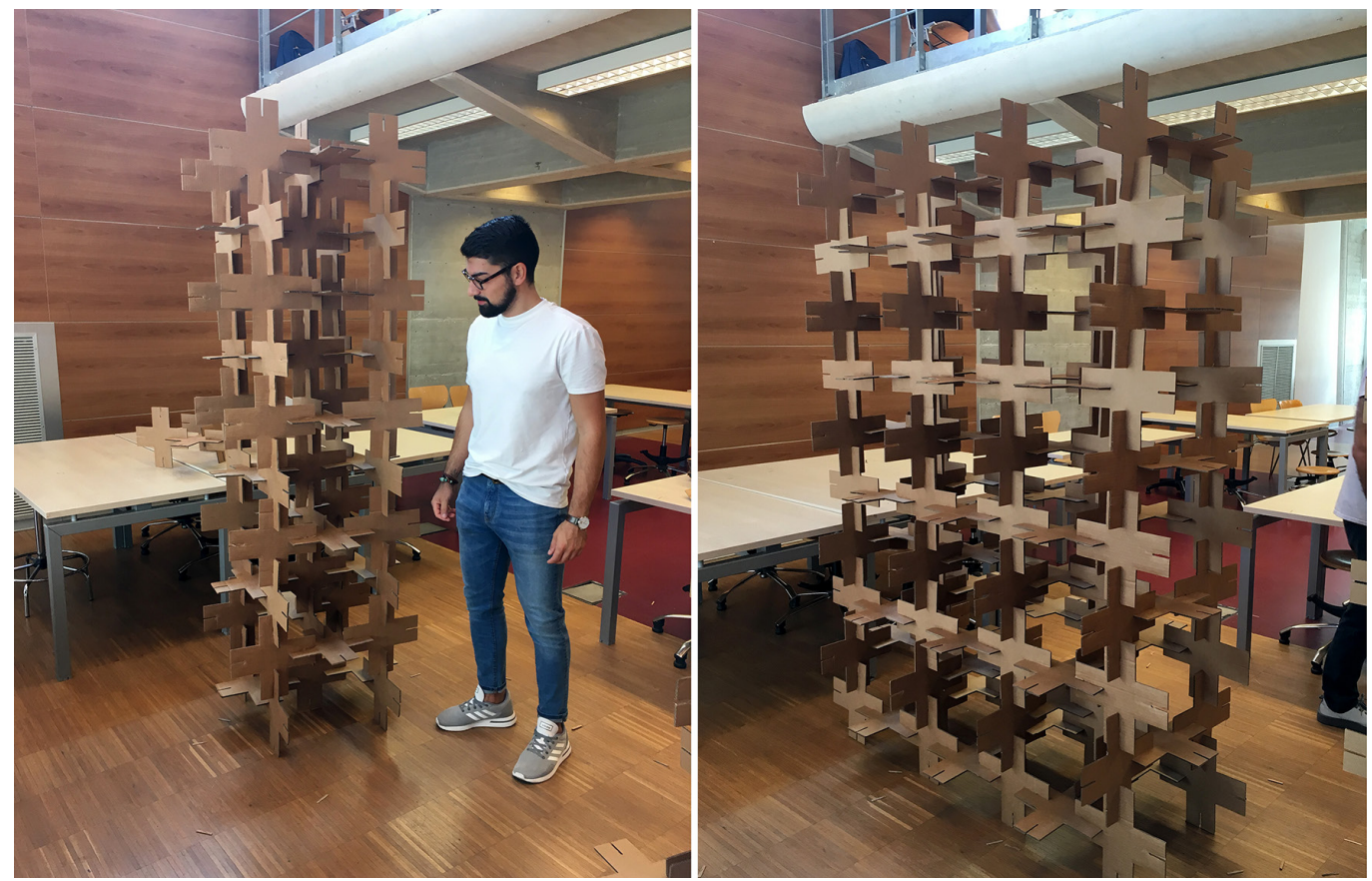


\section{L’attività ludica e i suoi principi teorici}

Il progetto ha previsto che all'interno del padiglione temporaneo si svolgessero una serie di attività ludico-didattiche ideate sulla base delle teorie dello sviluppo cognitivo concernenti, in particolare modo, due tipi di abilità, visuo-spaziali ed esecutive [Salmaso 20 I3]. Alla base degli studi sulle abilità visuo-spaziali troviamo proprio le definizioni di percezione e rappresentazione su cui numerosi studi, a partire dalla metà del 900, hanno focalizzato la propria ricerca. Pensiamo, per citare solo i più importanti, agli studi seminali di Piaget [Piaget, Inhelder 1976], Kanizsa (1980), Levine, Jankovic e Palij (1982) e Cornoldi (1997).

Come ben sappiamo, la rappresentazione mentale (e in generale qualsiasi forma di rappresentazione) della posizione che gli oggetti e le forme assumono nello spazio è uno strumento fondamentale per poter elaborare risposte e strategie successive alla percezione di uno stimolo. Inoltre, l'immagine visiva che elaboriamo mentalmente ci permette di modificare virtualmente anche ciò che non è direttamente visibile, consentendoci così di prefigurare nuove configurazioni, di effettuare confronti, stabilire somiglianze o differenze tra oggetti. Una capacità che è alla base della formazione dell'architetto, e che, in modo particolare le discipline della rappresentazione e del disegno, ampliano e rendono particolarmente efficace nonché indispensabile alla capacità creativa e progettuale [Antonietti 1999, Antonietti e Colombo 20II-20I2]. Numerose ricerche [Hanley, Levine 1983; Sgaramella, Bisiacchi, Falchero 2006; Albiero et al. 200 I] evidenziano come la creazione e gestione delle immagini mentali siano basilari per affrontare in modo efficace la soluzione di problemi concreti poiché consentono di riprodurre virtualmente nello spazio mentale le operazioni che si compierebbero nello spazio fisico tridimensionale prevedendo anche il possibile risultato di future azioni o processi.

Oltre alle capacità visuo-spaziali, il gioco delle costruzioni permette di sviluppare anche le cosiddette funzioni esecutive, ovvero insiemi di processi mentali come l'attenzione, la memoria di lavoro, il problem solving e la progettazione delle fasi [Welsh, Pennington, Groisser I99 I]. A tale proposito, Salmaso [Salmaso 20 I3, p. I69] riporta come relativamente a queste funzioni, in letteratura siano presenti due scuole di pensiero differenti. La prima, il modello Anderson (2002) punta l'attenzione sugli obiettivi da raggiungere attraverso le azioni

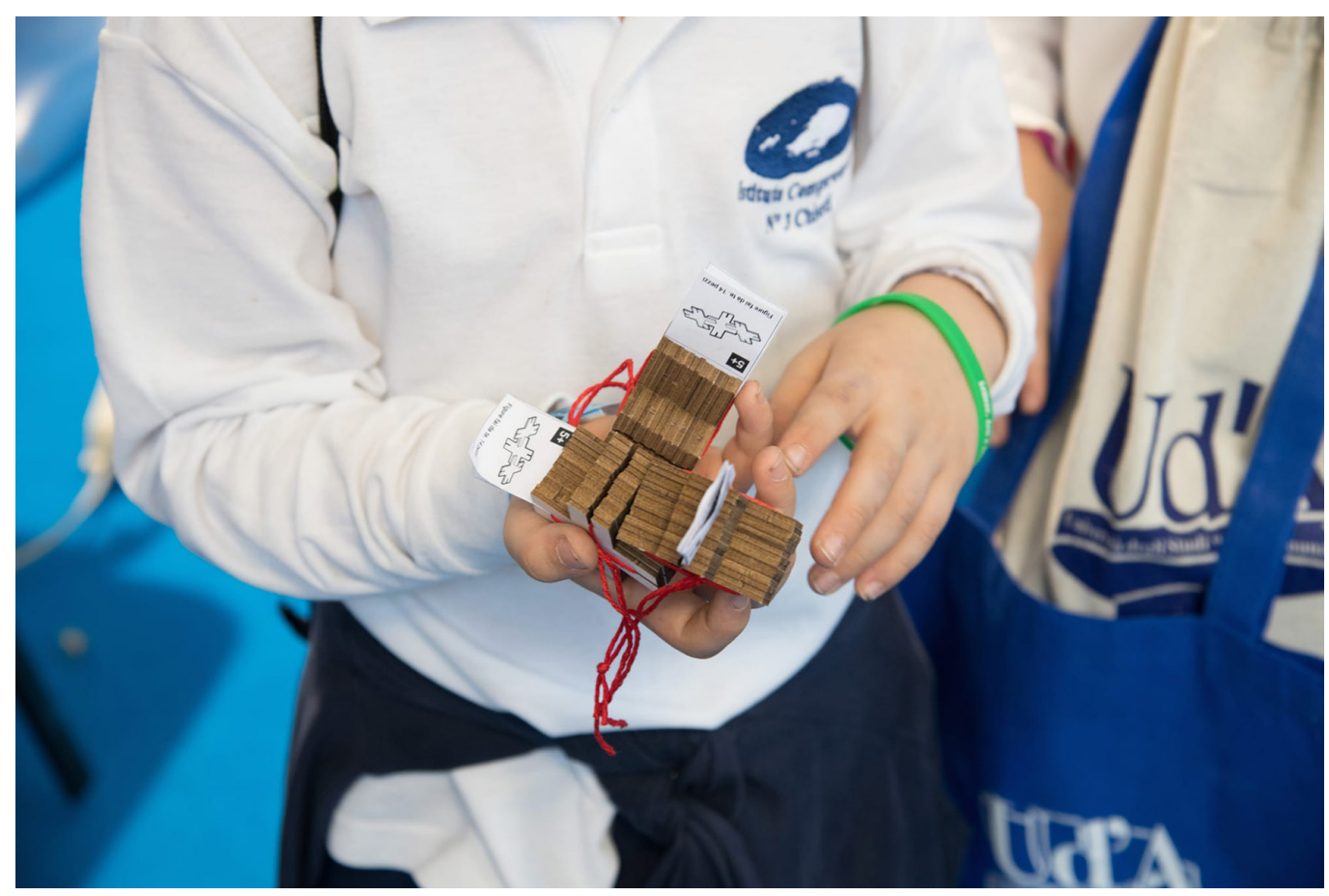


Fig. 6. Progetto iniziale di allestimento del padiglione del Dipartimento di Architettura.
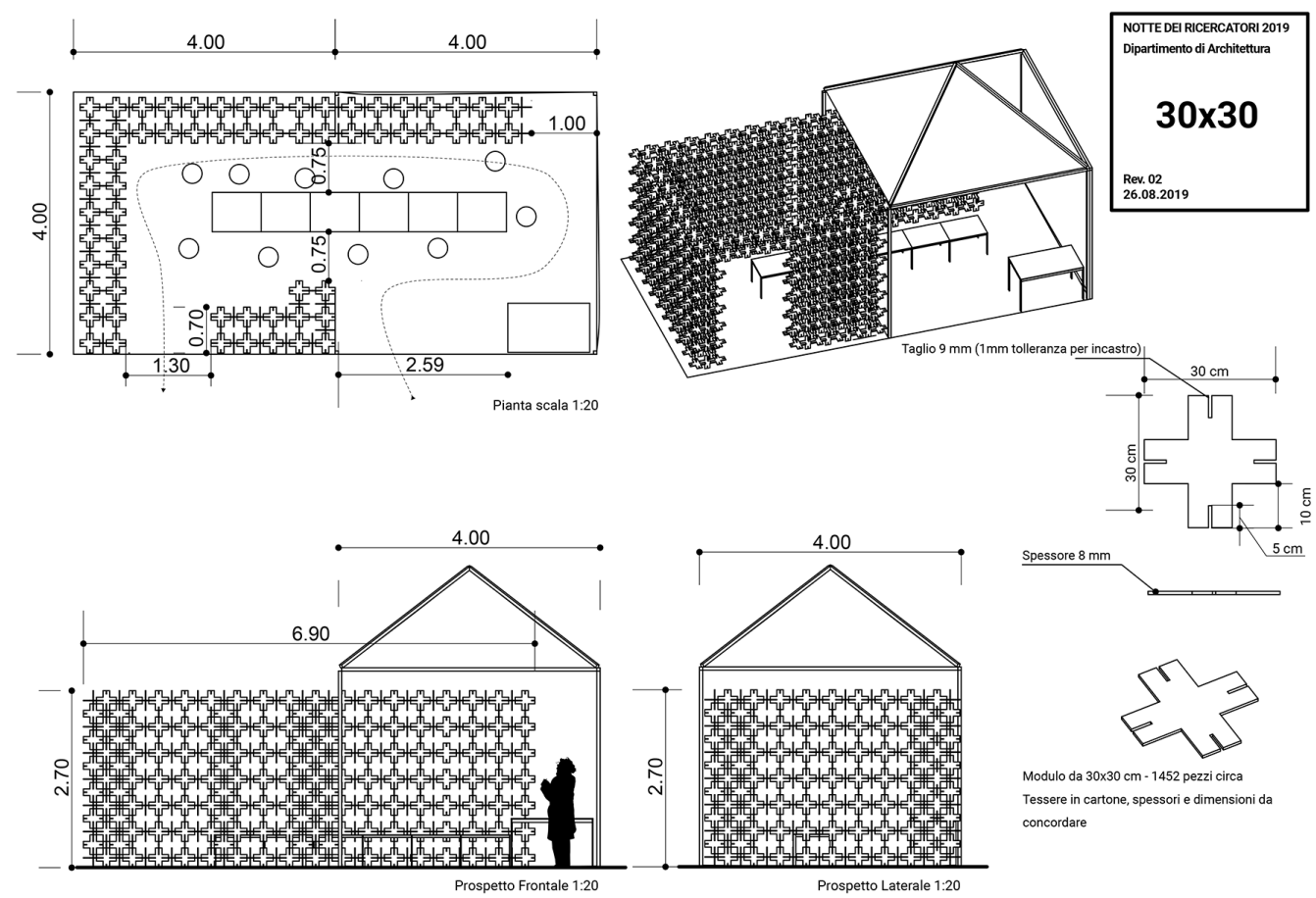

ludiche, in particolare la progettazione e l'articolazione delle fasi. Secondo alcune ricerche [Luciana, Nelson 2002; Anderson 2002] questo tipo di funzione esecutiva ha il suo momento di maggiore sviluppo nella fascia compresa tra i sette e i dieci anni, pertanto, stimolare questi processi attraverso il gioco delle costruzioni è molto utile per i bambini e bambine di questa età. II secondo modello, evidenziato da Burgess (2000), ha una visione sequenziale e integrata delle azioni che iniziano con la conoscenza delle regole del gioco, l'organizzazione dei passi da seguire, la realizzazione, la corrispondenza tra l'idea iniziale e la sua effettiva

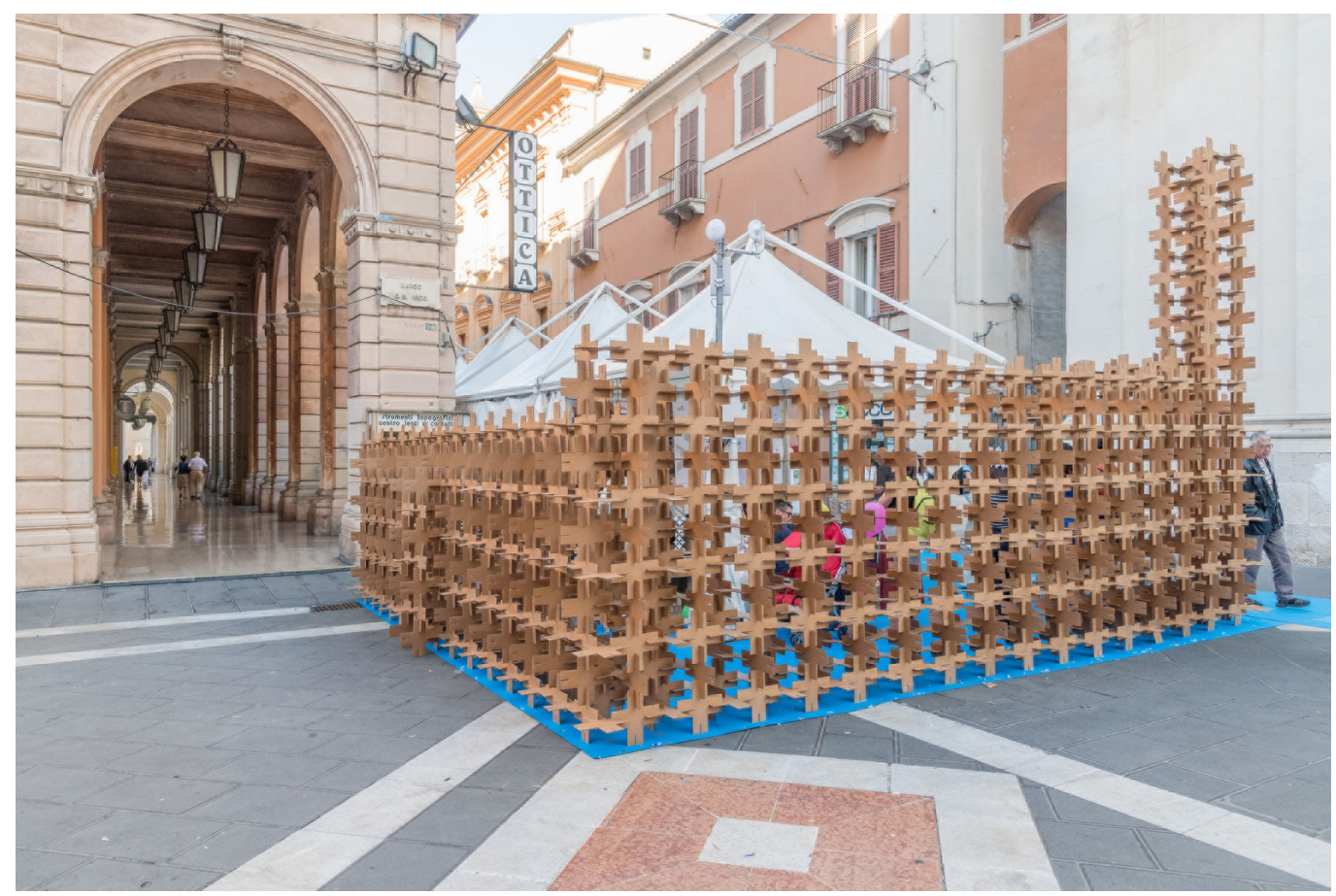


realizzazione per arrivare poi a una valutazione del manufatto e a eventuali miglioramenti. Come notiamo, si tratta di processi mentali che anticipano, attraverso il gioco quei passi, che sono alla base del disegno e della progettazione architettonica.

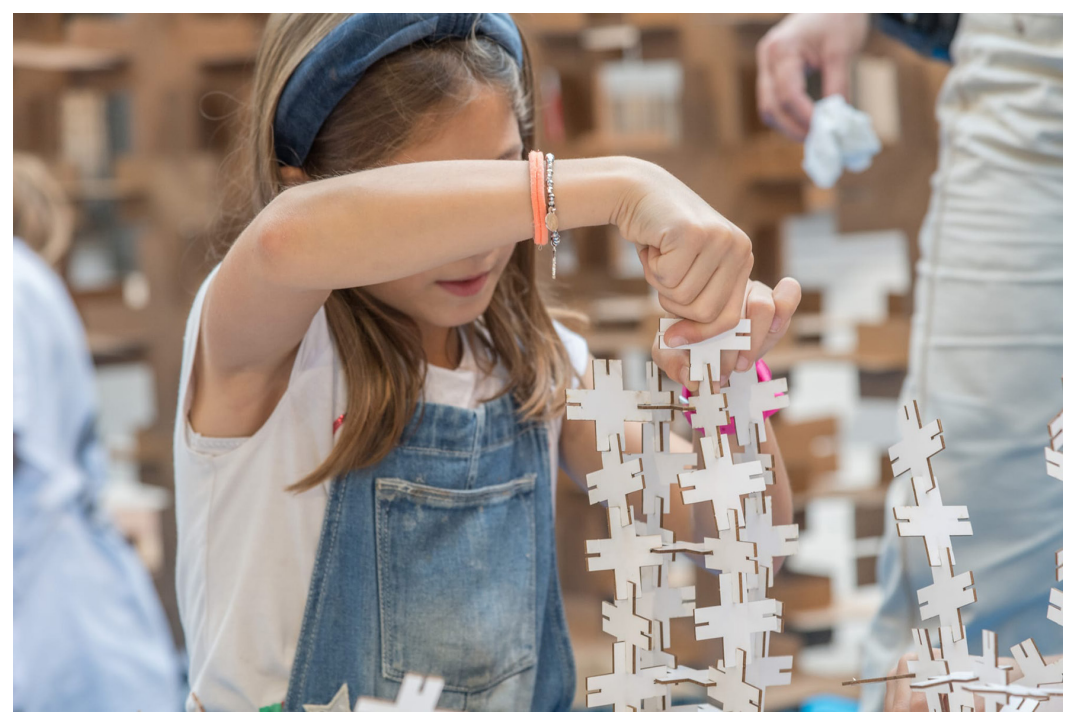

\section{Realizzazione del padiglione e svolgimento delle attività}

L'evento della Notte dei Ricercatori si è svolto in un'unica giornata in cui si sono succedute in tre fasi: montaggio del padiglione temporaneo nella mattinata, svolgimento delle attività ludiche nel pomeriggio e nella serata, smontaggio al termine dell'evento.

La prima fase è quella che ha visto coinvolti gli studenti e i dottorandi alle prese col montaggio delle pareti di tessere in cartone di $30 \times 30 \mathrm{~cm}$. II progetto originale (fig. 6) prevedeva uno spazio che duplicava esattamente quello del gazebo fornito dall'organizzazione, un quadrato $4 \times 4 \mathrm{~m}$. In realtà, problemi logistici e di organizzazione dei percorsi e degli accessi hanno fatto sì che lo spazio realmente a disposizione fosse nettamente minore rispetto a quello preventivato. Pertanto, l'allestimento è stato prontamente ripensato in base al nuovo spazio realizzando sempre un ampliamento dello spazio $4 \times 4$ che però ha assunto una configurazione più articolata. Le tessere che non sono state usate per realizzare gli elementi divisori preventivati sono state impiegate per creare una sorta di alta colonna che segnala la presenza dell'allestimento anche da notevole distanza (fig. 7).

In questa fase, sono stati gli stessi studenti a mettere in campo le abilità progettuali e costruttive proprie del gioco delle costruzioni, un modo per saggiare nel concreto i principi delle costruzioni modulari e la creazione di un oggetto architettonico che sia al tempo stesso funzionale e comunicativo.

La seconda fase ha visto coinvolti i visitatori dell'evento, iniziato alle 15:00 e proseguito fino a dopo la mezzanotte. Per i giocatori sono stati messi a disposizione oltre 4000 tessere di cartone $5 \times 5 \mathrm{~cm}$ distribuite liberamente su una serie di ampi tavoli posti all'interno del padiglione. Ai bambini e alle bambine che hanno partecipato sono state proposte attività di costruzione di differente e graduale complessità: attività iniziale individuale a ideazione libera; attività individuale di costruzione a partire da semplici modelli realizzati dai tutor; attività individuale di costruzione utilizzando disegni di modelli di differente articolazione; progettazione e costruzione di strutture libere a coppie; realizzazione in gruppo di strutture complesse libere integrando o unendo modelli già esistenti; a coppie, indovinare a turno l'identità del modello realizzato dal proprio compagno; infine, smontaggio del proprio modello per permettere agli altri giocatori di servirsi delle tessere per il proprio gioco (figs. 8, 9). 
Durante tutte la fase ludica, fondamentale è stato l'apporto dei tutor, studenti e laureati che hanno seguito il corso di Didattica del disegno e delle rappresentazioni grafiche nell'a. a. 2017-2018 e 2018-2019 [ []: i tutor hanno seguito i lavori dei bambini stimolandoli a sperimentare diverse configurazione di incastro, suggerendo opzioni costruttive, valorizzando i prodotti realizzati e gestendo la distribuzione delle tessere e degli spazi (fig. I0).

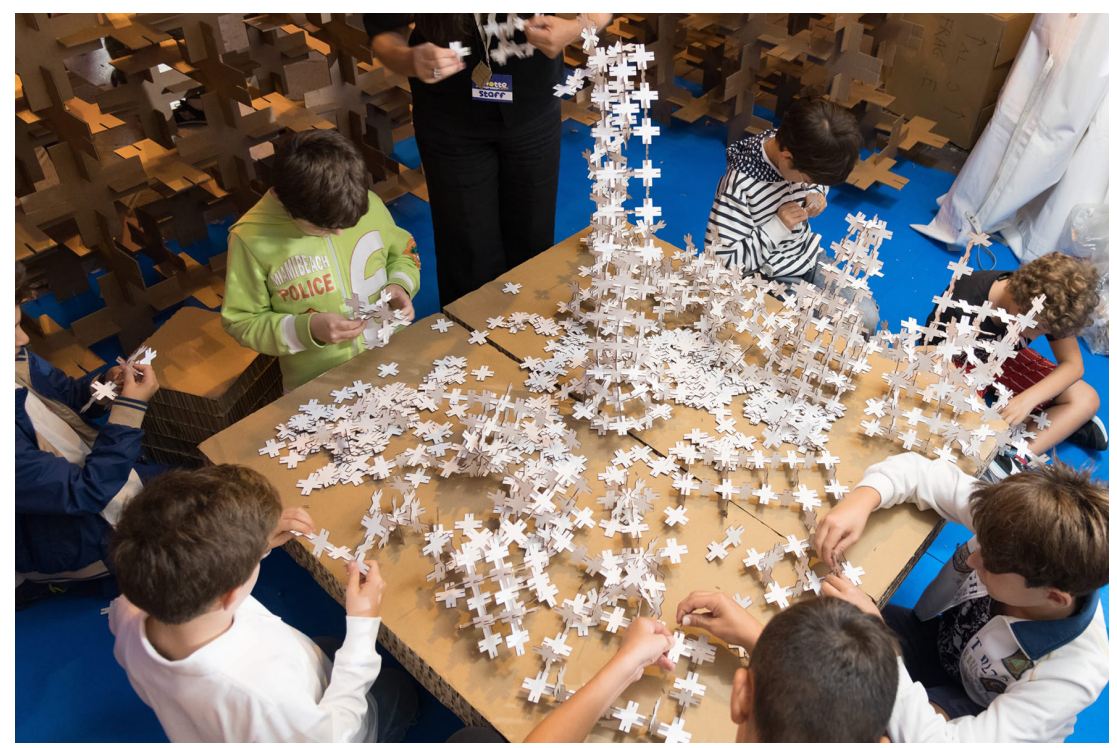

\section{Obiettivi ipotizzati e raggiunti}

Per quanto riguarda gli obiettivi messi in campo dalle attività ludiche svolte durante l'evento della Notte dei Ricercatori, abbiamo cercato di valorizzare soprattutto quelle abilità visuo-spaziali e di cooperazione più vicine al fare dell'architetto, senza far ricorso a modelli precostituiti e a esempi da riprodurre. Questo con il fine di rendere l'attività più inclusiva possibile lasciando che fossero gli stessi fruitori a cercare modalità personali di utilizzo. Uno

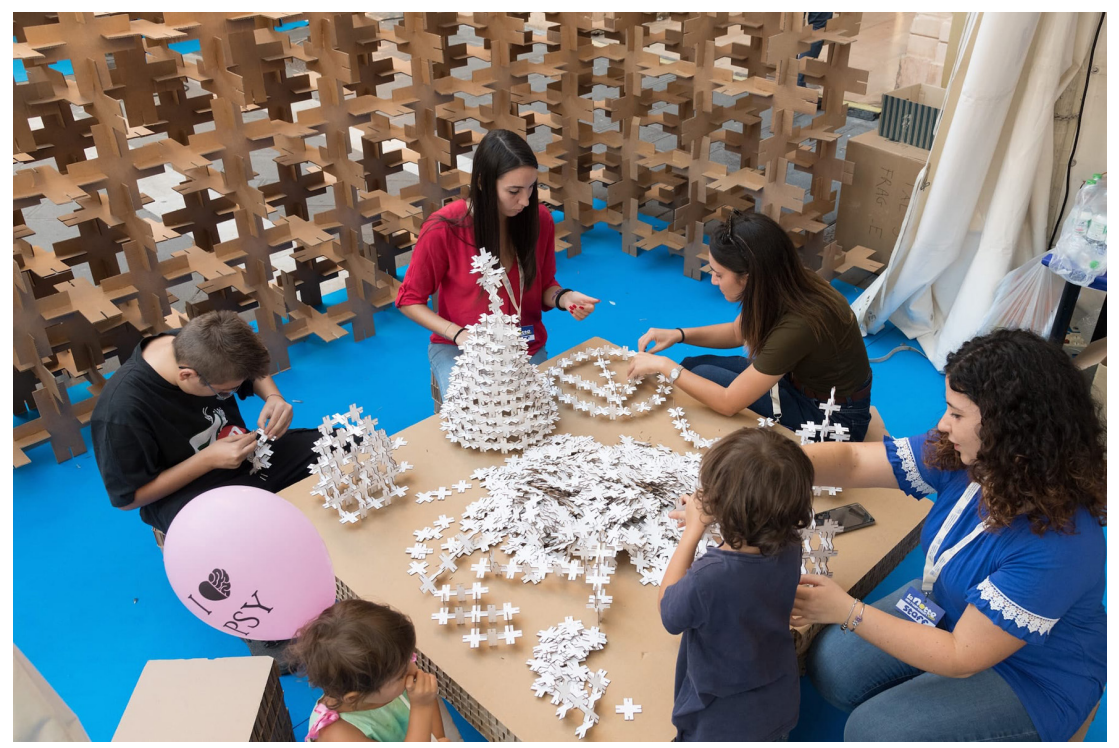


degli obiettivi didattici legati alla disciplina architettonica che ci siamo prefigurati di raggiungere, seppure nel breve tempo dedicato al gioco, è stato quello di stimolare i bambini a imparare a elaborare ipotesi progettuali. Durante il gioco delle eco-costruzioni, abbiamo notato come i bambini non siano quasi mai partiti da un'idea specifica riguardo a cosa costruire, ma abbiano ricercato delle soluzioni progettuali sempre diverse nate dalle differenti combinazioni di montaggio. Molto spesso i bambini si sono fatti prendere dal sistema di incastri anche casuali, scegliendo le combinazioni che ai loro occhi, in base a verosimiglianze o parallelismi morfologici, acquisivano un particolare significato. Una volta individuato il soggetto, il lavoro di aggregazione modulare seguiva un andamento più ragionato e razionale. Ognuna di queste idee progettuali può essere considerata come un grumo progettuale, un a sorta di morfema puriniano [Berizzi, Valeriani 20I4], intorno al quale sono costruite ipotesi più ampie e dettagliate in un continuo percorso di prove ed errori. Un meccanismo,

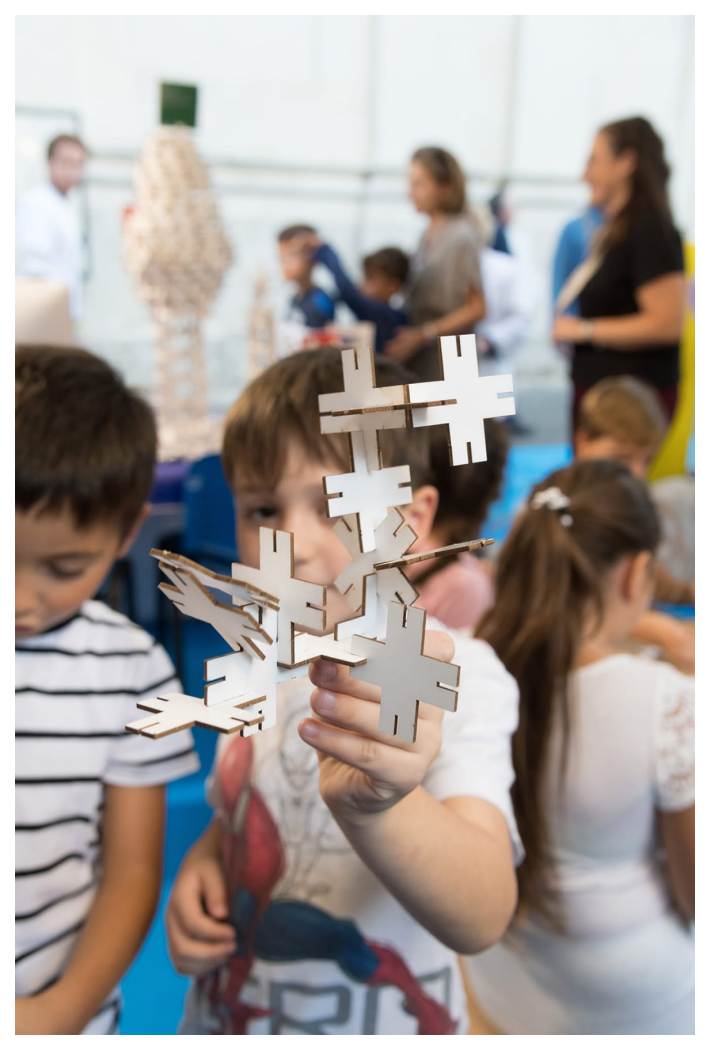

questo, che rivela un interessante parallelismo con l'attività libera e creativo del progettista che, attraverso lo schizzo, fa emergere nuovi significati e ipotesi che poi affina sempre di più per successivi passaggi (fig. I I).

Attraverso le eco-costruzioni sono stati sperimentati anche altri importanti obiettivi didattici che permettono di avvicinarsi ai principi dell'architettura: imparare a sperimentare concetti geometrici e spaziali gestendo le tessere a disposizione e creando configurazioni tridimensionali in grado di sostenersi e di non collassare per il proprio peso (esattamente come nelle costruzioni reali); migliorare le capacità di connettere la mano e la mente mettendo insieme idee, costruzione ed estetica; allenare le abilità inventive creando manufatti che possiedono una loro armonia e logicità interna visibile; infine, migliorare la capacità di lavorare a uno stesso progetto sviluppando diverse attitudini sociali quali comunicare, negoziare e condividere idee e fasi. 


\section{Conclusioni}

L'esperienza avvenuta durante l'evento della Notte dei Ricercatori 2019 è risultata positiva sia per gli studenti e docenti coinvolti nell'ideazione e realizzazione del sistema di eco-costruzioni modulari alle due scale, sia per le numerose famiglie e i numerosissimi bambini che hanno assistito e partecipato alle attività ludiche. La realizzazione del gioco e dell'allestimento hanno dimostrato una grande potenzialità per la creazione di uno spazio sensorialmente ricco, stimolante e inclusivo all'interno del quale è potuto avvenire in modo fluido e naturale l'incontro e il dialogo tra università e cittadini, tra ricercatori e persone comuni, tra studenti universitari e bambini. II gioco è stato lo strumento di apprendimento privilegiato attraverso cui i piccoli architetti hanno potuto esplorare strutture di aggregazione nello spazio.

E stata un'occasione unica e proficua per far sperimentare nel concreto il passaggio dal modulo di base alla struttura complessa, dal gioco delle costruzioni alla costruzione architettonica vera e propria in cui micro e macro si toccano, all'interno di una cornice accogliente dentro la quale ogni voce diversa può esprimersi e dialogare arricchendo la comunicazione e lo scambio di esperienze, un luogo di incontro che, al pari delle aule universitarie, si basa sui principi del rispetto e della cooperazione.

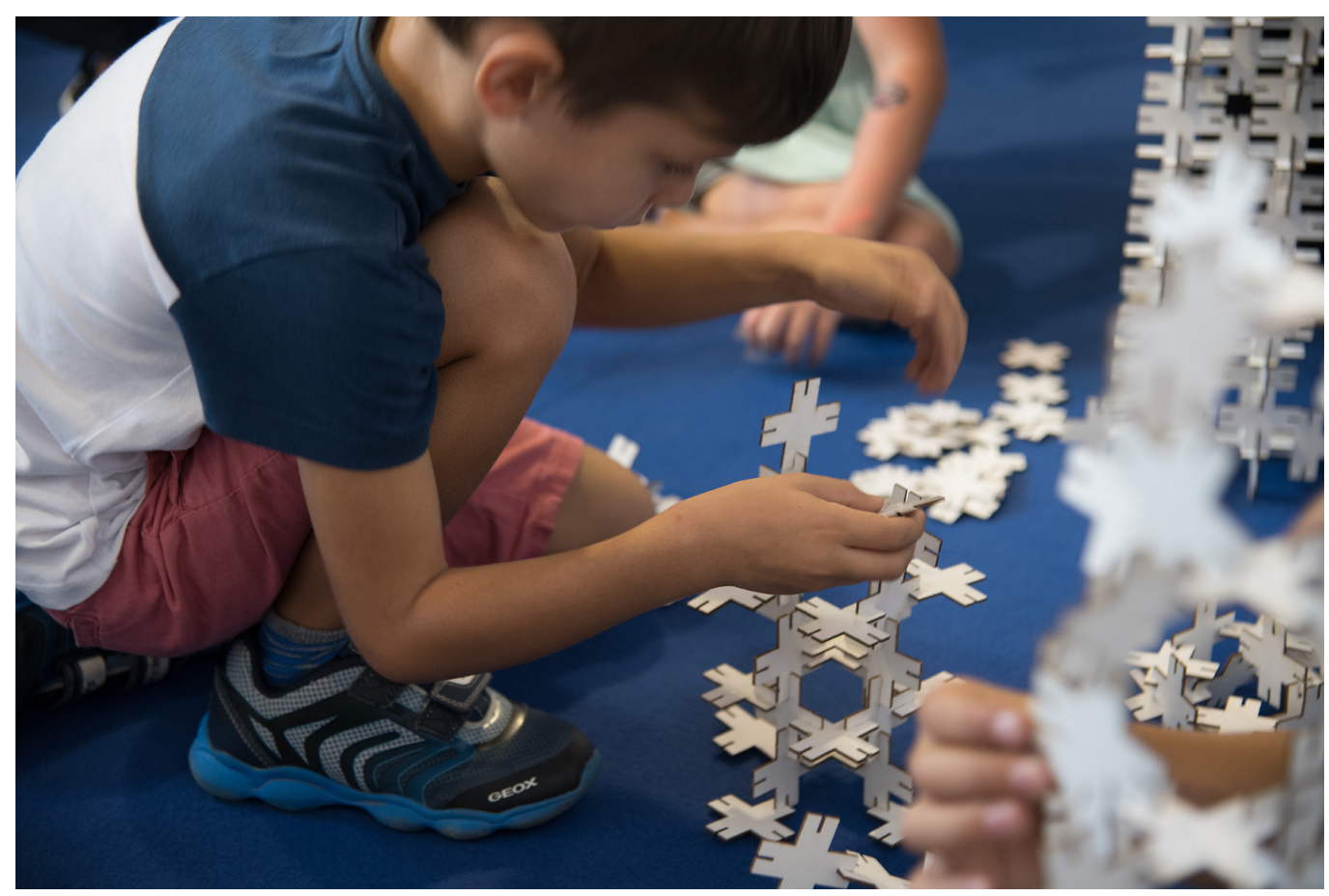

Note

[I] Gruppo di tutor e supporto composto da: Agnese Altieri, Diego Bocchini, Tonino Bucciarelli, Niccolò Cinti, Chiara Di Egidio, Noemi Di Toro, Giovanna Eliantonio, Giuseppe Marino, Matteo Milinanni, Maria Luisa Pontone, Rosa Perdonò e Chiara Tuttolani.

\section{Riferimenti bibliografici}

Albiero Paolo et al. (200 I). Abilità di pianificazione e memoria di lavoro visuo-spaziale in soggetti di età scolare. In Età evolutiva, 68, pp. $21-33$.

Anderson Peter (2002). Assessment and development of executive function during childhood. In Child Neuropsychology, 8 (2), pp. $7 \mathrm{I}-82$.

Antonietti Alessandro. (1999). Can student predict when imagery will allow them to discover the problem solution? In European Journal of Cognitive Psychology, I I, pp. 407-428. 
Antonietti Alessandro, Colombo Barbara. (201 I-20I2). Mental imagery as a strategy to enhance creativity in children. In Imagination, Cognition and Personality, 31, pp. 63-77.

Berizzi Carlo,Valeriani Enrico (a cura di). (20/4). A colloquio con Franco Purini. Roma: Gangemi Editore.

Burgess Paul W. et al. (2000). The cognitive and neuroanatomical correlates of multitasking. In Neuropsychology, 38, pp. 848-863.

Cornoldi Cesare (1997). Abilità visuo-spaziali: Intervento sulle difficoltà non verbali di apprendimento. Trento: Erickson.

Hanley Gerard, Levine Marvin (1983). Spatial problem solving, the integration of independently learned cognitive maps. In Memory and Cognition, II, pp. 415-422.

Kanizsa Gaetano (1980). Grammatica del vedere: Saggi sulla percezione e sulla Gestalt. Bologna: II Mulino.

Levine Marvin, Jankovic Irwin, Palij Michael (1982). Principles of spatial problem solving. In Journal of Experimental Psychology, । I।, pp. 157-175.

Luciana Monica, Nelson Charles A. (2002). Assessment of neuropsychological function through use of the Cambridge Neuropsychological Testing Automated Battery Performance in 4 to 12-year-old children. In Developmental Neuropsychology, 22 (3), pp. 595-624.

Maas Winy (2019). I ragazzi sono gli urbanisti di domani. In Domus, I031, 2019, pp. I0- 17.

Marcolli Attilio (1978). Teoria del campo: corso di educazione alla visione. Milano: Sansoni.

Mirri Franco (1992). La rappresentazione tecnica e progettuale: manuale di disegno per ingegneri e architetti. Roma: NIS.

Munari Bruno (1972). Design e comunicazione visiva: contributo a una metodologia didattica. Bari Laterza, 1972.

Piaget Jean, Inhelder Bärbel ( 1976). La rappresentazione dello spazio nel bambino. Firenze: Giunti Barbera.

Salmaso Luisa (2013). Le potenzialità del gioco con i mattoncini Lego nella Scuola Primaria. In TD Tecnologie Didattiche, 2 I (3),

Autore

Giovanni Caffıo, Università degli Studi “G. d'Annunzio", Chieti-Pescara, giovanni.caffio@unich.it

Per citare questo capitolo: Caffio Giovanni (2020). +X+. Un progetto di eco-costruzioni ludiche per insegnare i principi dell'architettura modulare/ $+X+$. A project of playful eco-Bbocks to teach the principles of modular architecture. In Arena A., Arena M., Brandolino R.G., Colistra D., Ginex G., Mediati D., Nucifora S., Raffa P. (a cura di). Connettere. Un disegno per annodare e tessere. Atti del $42^{\circ}$ Convegno Internazionale dei Docenti delle Discipline della Rappresentazione/Connecting. Drawing for weaving relationships. Proceedings of the 42th International Conference of Representation Disciplines Teachers. Milano: FrancoAngeli, pp. 174-195. 


\title{
$+X+$. A Project of Playful Eco-Blocks to Teach the Principles of Modular Architecture
}

\author{
Giovanni Caffio
}

\section{Abstract}

This paper presents a multidisciplinary experience carried out for the Department of Architecture of Pescara on the occasion of the Researchers' Night 2019 (held in Chieti on 27 September 2019) in which drawing, design, installation, institutional communication and recreational activities come together and collaborate to bring a heterogeneous public, and in particular school and pre-school children, closer to the world of research and teaching in architecture. The design and construction of the temporary pavilion and of the recreational activities, based on the game of eco-blocks designed for the occasion, have allowed to highlight useful elements to confirm the usefulness of the construction game for the improvement of visualization and spatialization, problem solving and cooperation in an inclusive key.

Keywords

didactics; drawing; game; construction; installation.

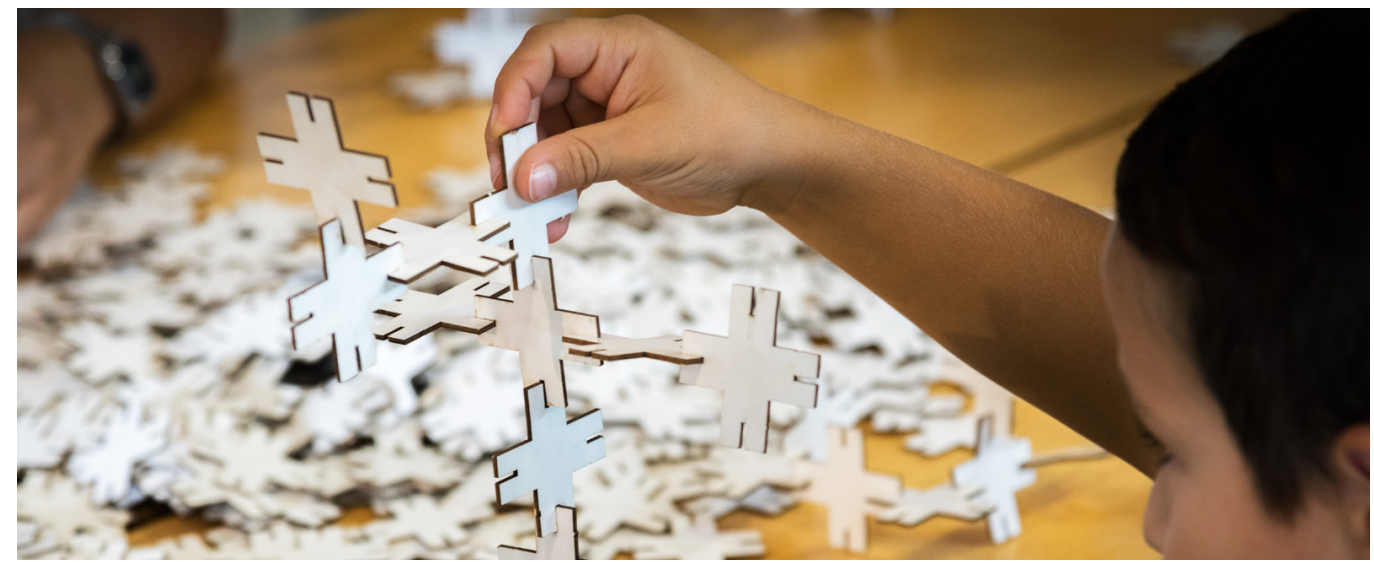




\section{Introduction}

This paper describes and analyzes a design and playful experience of the Department of Architecture of Pescara carried out during the Researchers' Night 2019 which took place in Chieti on September 27, 2019. The experience stems from the need to communicate in a simple and direct way the activities and the mission of the Department of Architecture to an audience consisting largely of families and children. Researchers' Night is an initiative supported by the European Commission which, started in 20 I5, takes place every year, activating thousands of researchers and research centres in all European countries. It is an important occasion in which university researchers and ordinary citizens meet and dialogue with the aim of expanding scientific culture and enabling them to understand the commitment and value of scientific professions within non-formal and inclusive frameworks. From the very beginning Italy has joined the initiative, becoming one of the countries with the highest number of events scattered throughout the country. In 2019 the project involved II projects for a total of 116 cities including Chieti and Pescara.

In 2018 the Researchers' Night event took place over two days: the first one in Pescara and the second one in the streets of the centre of Chieti where stands and pavilions - related to the orientation and description of the different degree courses, informative conferences and shows, live scientific demonstrations, guided tours of exhibitions and shows, but above all many recreational-educational activities - were set up to entertain and inform large numbers of students, coming mainly from primary schools.

Based on the experience of the previous year, in 2019 the group in charge of the planning and realization of the event (directed by the Director of the Department, Prof. Paolo Fusero and coordinated by the writer and with the collaboration of PhD students and students from different degree courses, as well as assisted by the technical-administrative staff) decided to structure the space made available to the Department as a place of experimentation and play in which, rather than illustrating the results of the research and teaching in progress, space was given to experimenting with the basic principles of architectural design, a playful activity that would show, through free and creative action, the methodological assumptions

Figs. I, 2. Design of modular blocks and their interlocking possibilities. Poster of the event with some possible aggregations.

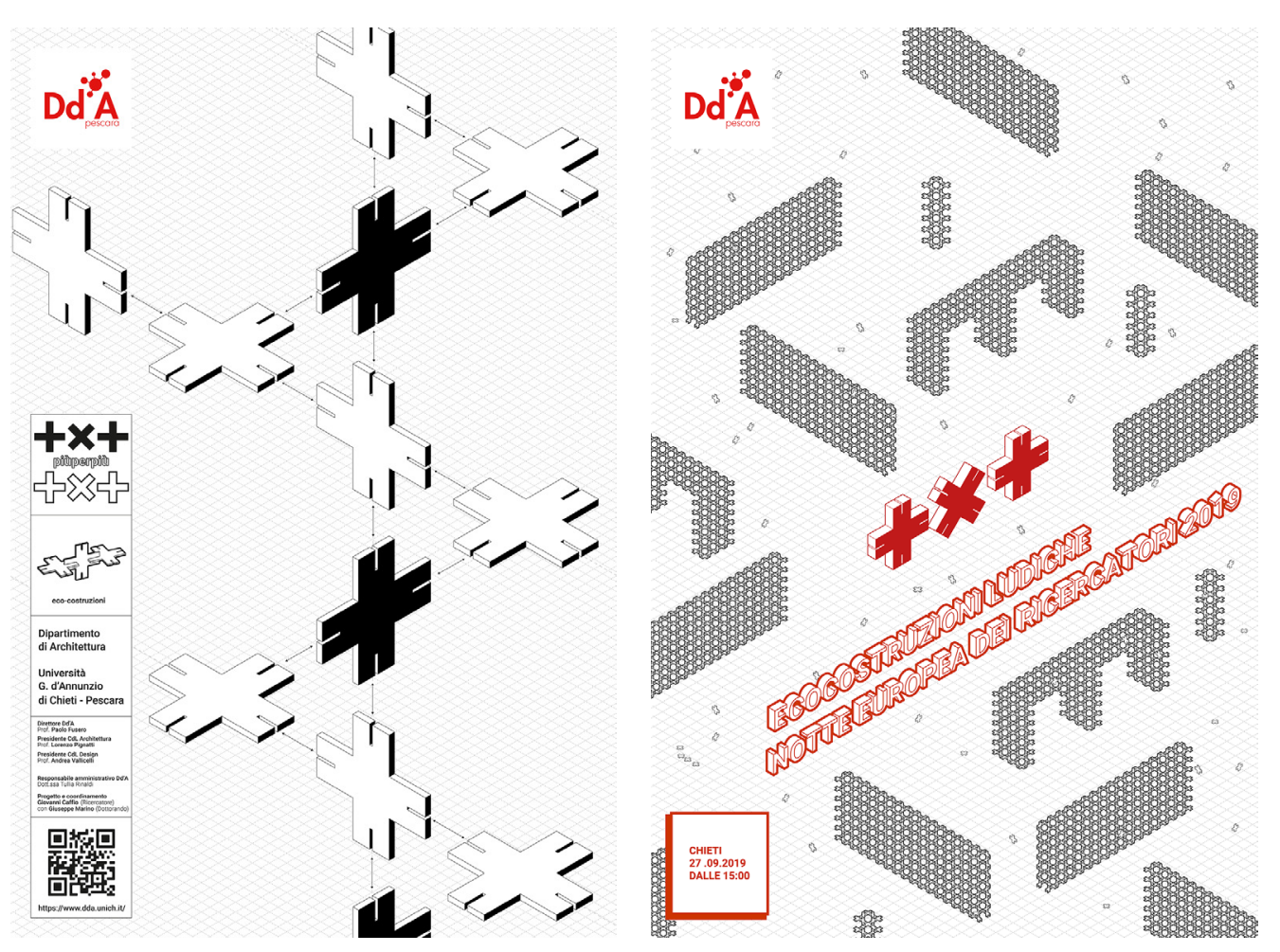


that are at the basis of the creative path experimented in all disciplines that collaborate in the training of the architect.

The choice, therefore, did not focus on specific results or methodologies but on the concrete experimentation of fundamental constructive and compositional actions, a way to bring an audience, especially young people, closer to the principles of architecture in a concrete and playful way. Given these premises, after having examined various hypotheses, the decision fell on the idea of working on the construction-bricks game, certainly one of the most popular activities in childhood but which does not always find space as a teaching tool in primary and secondary school despite its high skills in the learning field. This playful activity, in fact, is based on concrete and manipulable actions, encourages learning and reasoning processes based on the principle of learning by doing and allows its users to literally bring into play superior skills according to ludic and creative attitudes.

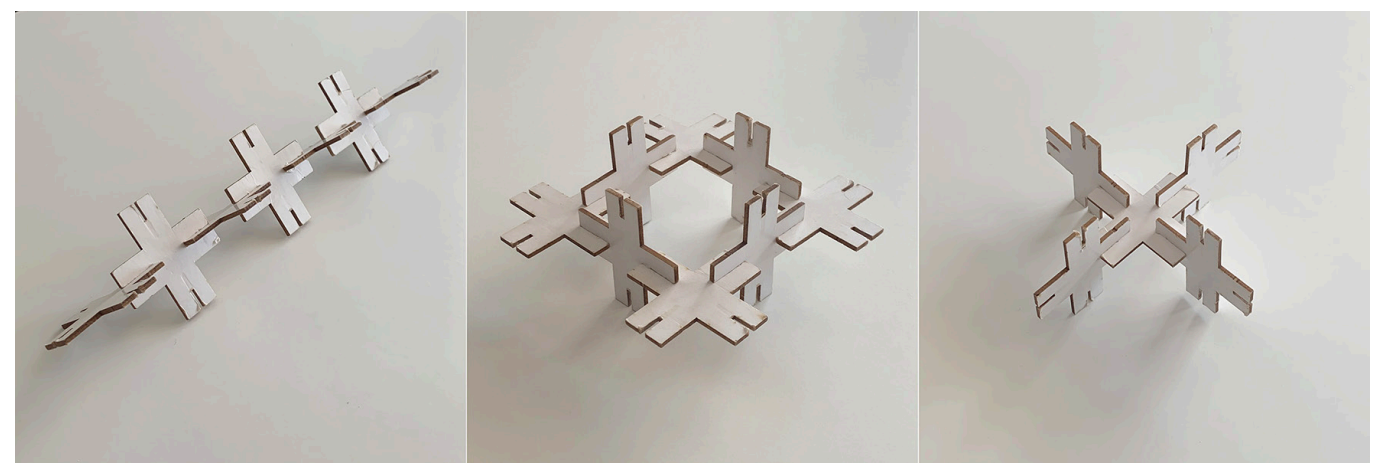

\section{The project}

The first step was to analyze the construction toys on the market based on recent public laboratory experiences such as those conducted by Winy Maas and Olafur Eliason. The first one, in November 20 I8, carried out an interesting workshop entitled Milano Futura in which 38 third-year students from a secondary school in Milan were involved. The aim was to re-imagine the city from its own neighbourhood using Lego bricks as material [Maas 2019]. Olafur Eliasson, on the other hand, created a large space for the creation of models within his own exhibition held at the Tate Modern in London from 28 July to 18 August 2019.Visitors were able to use thousands of white bricks to create models that together represent a collective and progressive vision of a future city. A collective work created by disassembling, connecting and reconstructing the elements left by each participant. This work, entitled The cubic structural evolution project, was presented for the first time in 2004 at the Queensland Art Gallery \& Gallery of Modern Art using unbranded Lego bricks without instructions. Market research has shown that in the vast majority of commercial toys the most widely used material is plastic, which creates quite a few problems in the management and disposal of these toys. Moreover, even if the plastic material is more resistant and versatile in terms of shapes, colours and models, it does not have the tactile and sensorial characteristics that characterize natural materials. Since the theme of Researchers' Night 2019 was sustainability, we discarded the most well-known bricks and focused our attention on natural alternatives, such as Kapla-type wooden constructions which, although more consistent with the theme of sustainability and the tactile characteristics of the most advanced toys, do not lend themselves to articulated and sophisticated types of construction, remaining mostly confined to a very young age group. For this reason, we decided to design and build a playful construction system that would meet our initial requirements, i.e. be made of natural, recyclable and sustainable materials, as well as being able to create modular aggregations of sufficient complexity. 
The starting point for this project was the study of graphic-modular systems such as those studied in the field of representation by scholars such as Bruno Munari (1972), Attilio Marcolli (1978) and Franco Mirri (1992). For the design of the basic module, we choose a geometric shape that was simple to manage in the production phase, flexible and with a sufficient number of aggregation possibilities: the flat geometric figure of the square. The type of interlocking, also very simple, is the 'half wood' type. In this joint, on the sides of the square are made four slots that have the width equal to the thickness of the card and the depth equal to I/4 of the side of the square. In this type of joint, two tiles are interlocked by rotating one with respect to the other by 90 degrees. The next step was to modify the basic square to reduce the amount of material to be processed, leaving the solidity of the joints intact. After several attempts the choice fell on a Greek cross pattern where the short sides are exactly $1 / 3$ of the side of the base square and the depth of the slots has been reduced to $1 / 6$ of the base square (figs. I, 2).

This type of interlocking allows basic combinations that can be linear; square base with 5 modules and square base with 8 modules and all the infinite combinations that arise from the aggregation of these basic forms (fig. 3).

It was decided to produce two versions of this modular system: the first, aimed at playing construction for children, has a size of $5 \times 5 \mathrm{~cm}$ and is made of pressed cardboard and covered with white paper then cut with a laser plotter; the second, designed to make part of the exhibition pavilion, adopts $30 \times 30 \mathrm{~cm}$ corrugated cardboard tiles $4 \mathrm{~mm}$ thick die-cut (fig. 4). The blocks for the game were made in 9300 pieces (of which 4200 used for free play and 5100 used for game kits that were given as gadgets to the young participants) (fig. 5) while those for the construction of the installation were produced in a number of 4200 pieces. These eco-bricks, named "+x+", represent a low cost but effective technology and, although they do not possess the 'indestructibility' of plastic bricks, they have in themselves the sense of a limited duration, typical of natural resources. In this sense, their use and gradual deterioration reinforce the idea of a conscious and sustainable use of raw materials: an implicit and concrete ecological message.
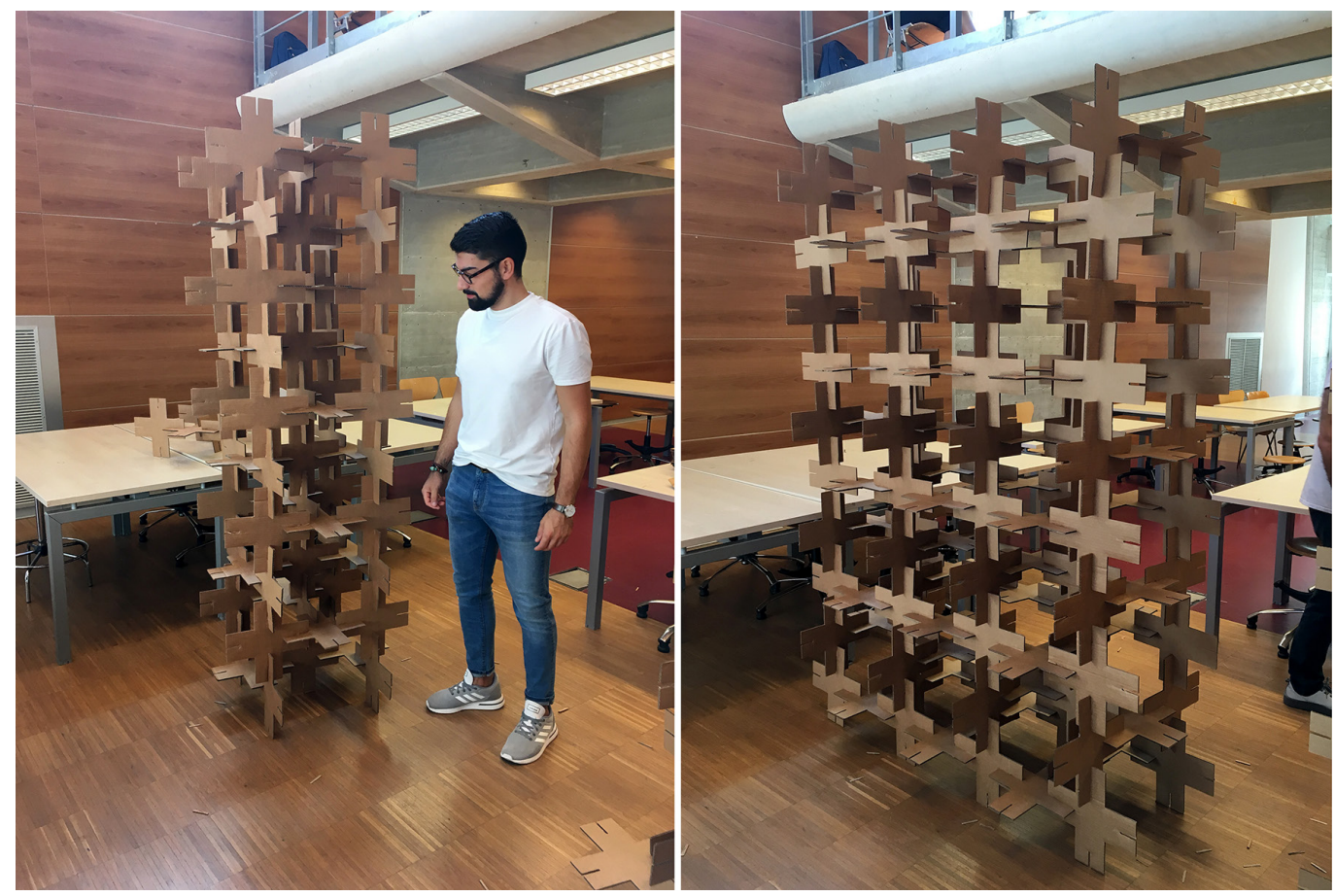


\section{Ludic activity and its theoretical principles}

The project foresaw in the temporary pavilion a series of ludic-didactic activities too take place, conceived on the basis of cognitive development theories concerning, in particular, two types of skills, visual-spatial and executive [Salmaso 20I3]. At the basis of the studies on visual-spatial abilities we find the definitions of perception and representation on which many studies, starting from the mid-twentieth century, have focused their research. Let us think, just to mention the most important ones, to the seminal studies by Piaget [Piaget Inhelder 1976; Kanizsa 1980; Levine, Jankovic, Palij I982; Cornoldi 1997].

As well known, the mental representation (and in general any form of representation) of the position that objects and forms assume in space is a fundamental skill to be able to elaborate responses and strategies after the perception of a stimulus. Moreover, the visual image that we mentally process allows us to virtually modify even what is not directly visible, thus allowing us to prefigure new configurations, make comparisons, establish similarities or differences between objects. A capacity that is at the basis of the architect's training, and which, in particular, the disciplines of representation and drawing expand, make particularly effective and indispensable to the creative and design ability [Antonietti, 1999; Antonietti, Colombo 20II-20I2]. Numerous researches [Hanley, Levine 1983; Sgaramella, Bisiacchi, Falchero 2006; Albiero et al. 200 I] show how the creation and management of mental images are fundamental to effectively face the solution of concrete problems allowing to virtually reproduce, in the mental space, those operations that would be carried out in the three-dimensional physical space also foreseeing the possible result of future actions or processes.

In addition to the spatial-visual capabilities, the construction game also allows the development of so-called executive functions, i.e. sets of mental processes such as attention, working memory, problem solving and phase design [Welsh, Pennington and Groisser I99 I]. In this regard, Salmaso [Salmaso 2013, p. 169] reports how, in relation to these functions, two different schools of thought are present in the literature. The first, the Anderson model (2002) focuses on the goals to be achieved through playful actions, in particular the design

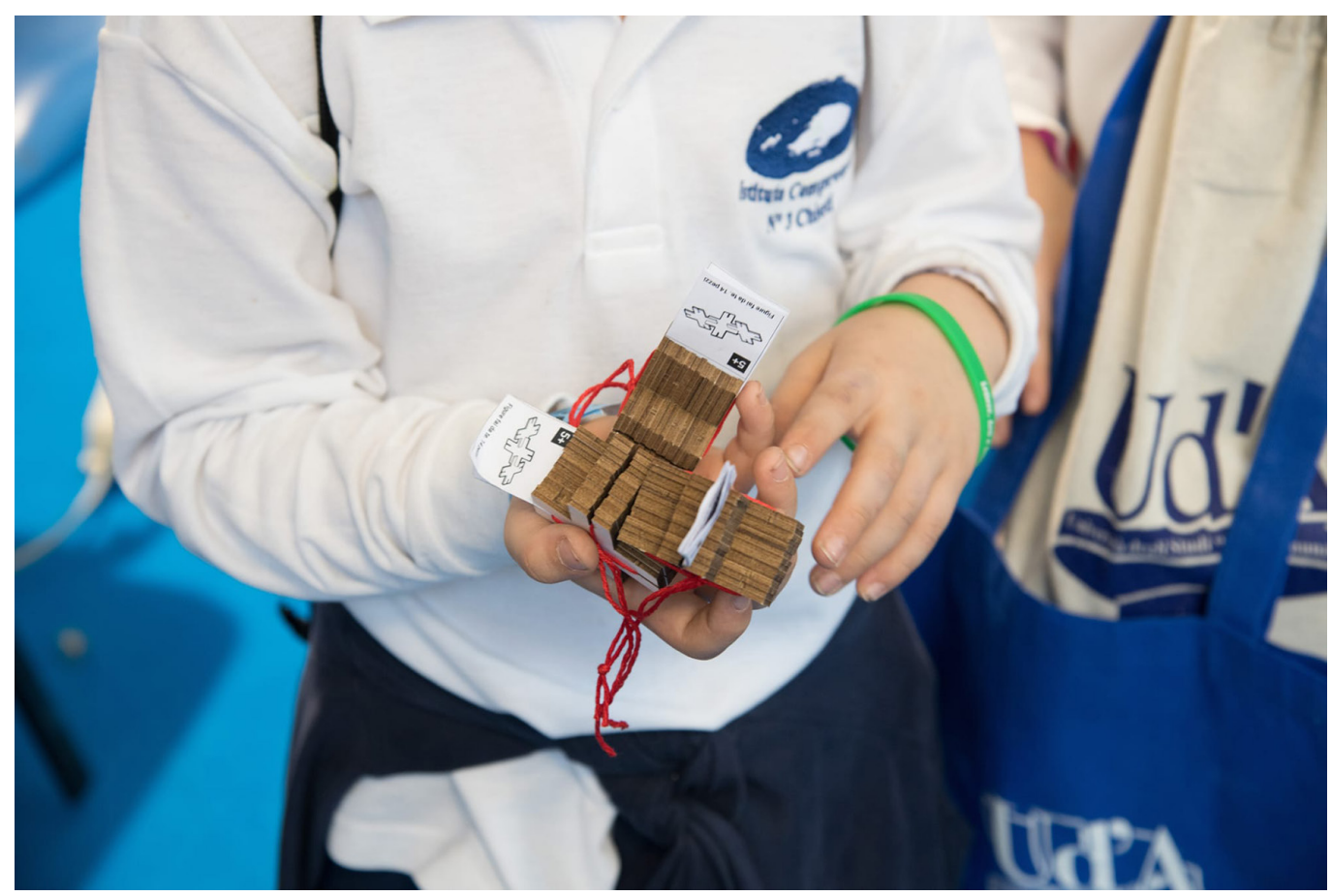


Fig. 6. Initial design of the Department of Architecture pavilion.
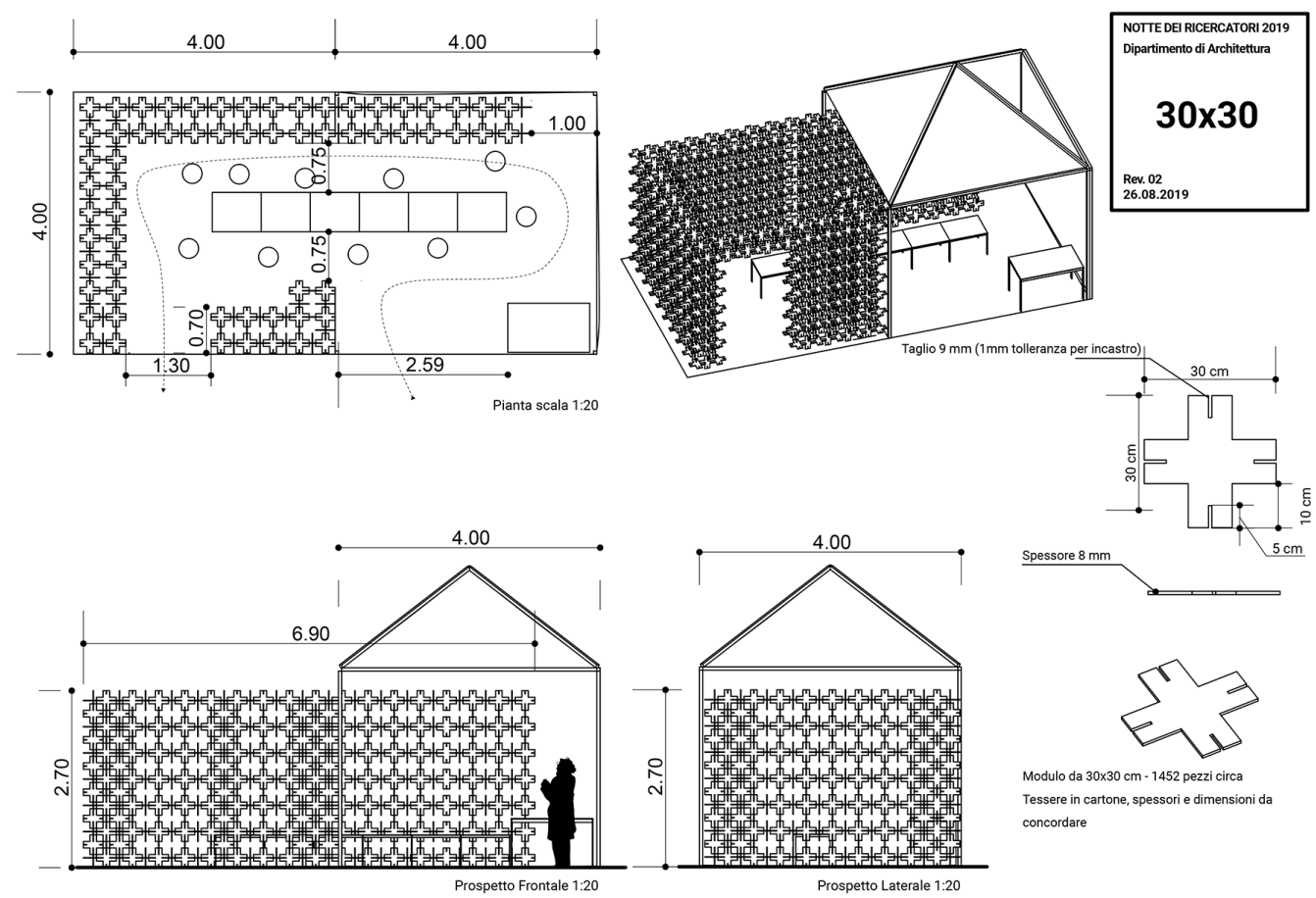

and articulation of phases. According to some researches [Luciana, Nelson 2002; Anderson 2002] this type of executive function has its moment of greatest development in the seven to ten years old age group, therefore, stimulating these processes through the play of construction is very useful for boys and girls of this age. The second model, highlighted by Burgess [Burgess 2000], has a sequential and integrated vision of the actions that begin with the knowledge of the rules of the game, the organization of the steps to follow, the realization, the correspondence between the initial idea and its actual realization before

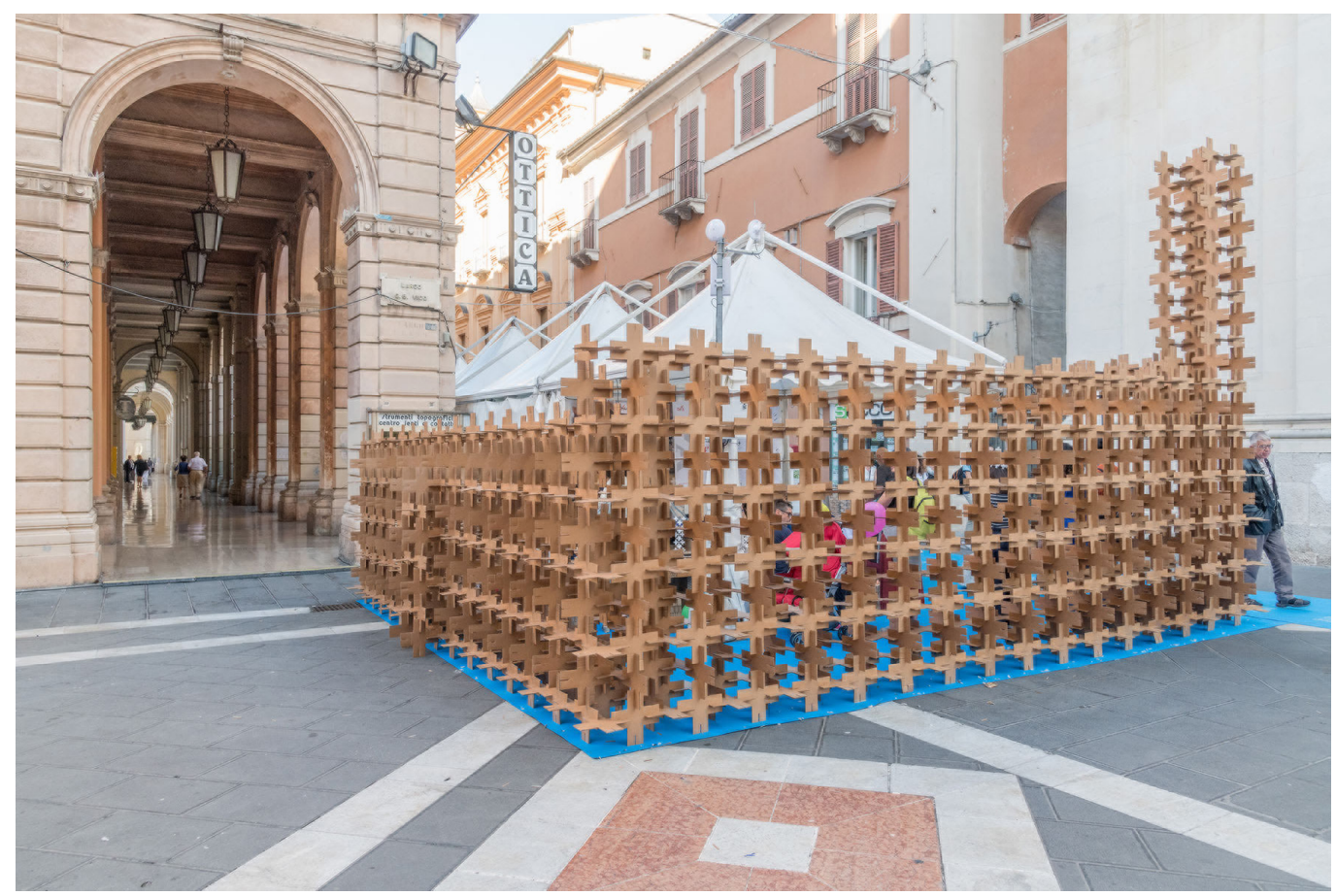


arriving at an evaluation of the manufactured article and its possible improvements. As we note, these mental processes anticipate, through the game, those steps which are the basis of architectural design and planning.

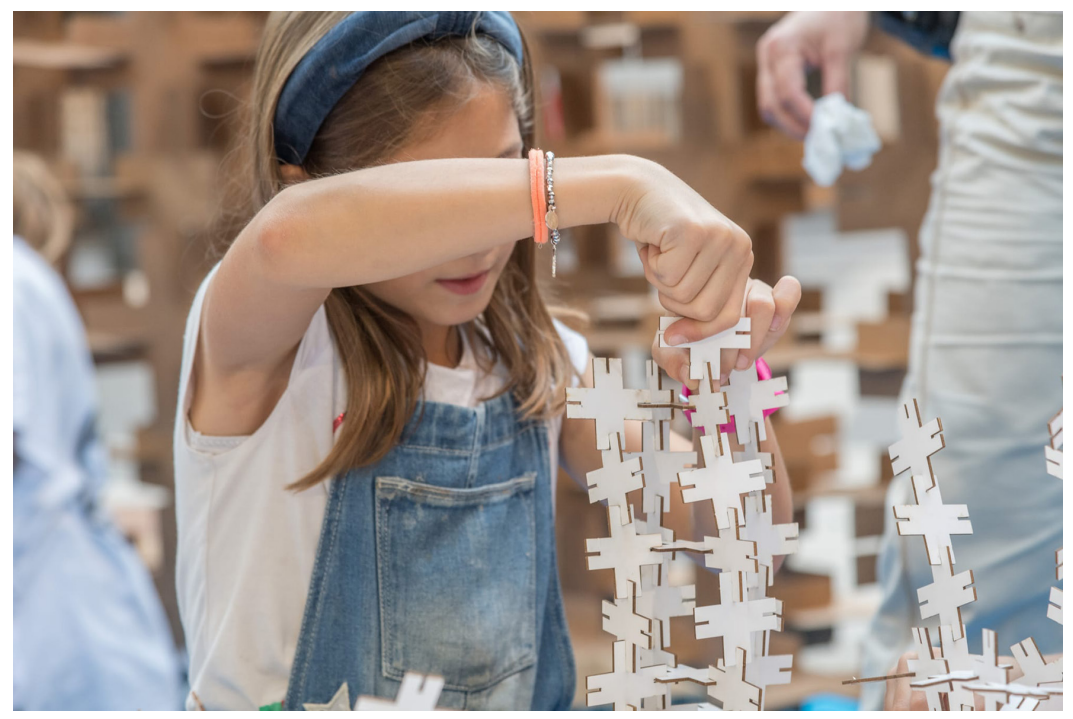

\section{Construction of the pavilion and performance of activities}

The Researchers' Night event took place on a single day in three phases: assembly of the temporary pavilion in the morning, play activities in the afternoon and evening and, finally, dismantling at the end of the event.

The first phase is the one in which students and $\mathrm{PhD}$ students were involved with the assembly of the walls of $30 \times 30 \mathrm{~cm}$ cardboard tiles. The original project (fig. 6) envisaged a space that exactly duplicated the $4 \times 4 \mathrm{~m}$ square of the gazebo provided by the organization. Actually logistical problems and difficulties in organizing the routes and accesses meant that the space available were much smaller than the planned one. Therefore, the layout was promptly rethought according to the new space, always creating an extension of the $4 \times 4$ space, which, however, took on a more articulated configuration. The tiles that were not used to create the planned dividing elements were used to create a sort of high column that indicates the presence of the set-up even from a considerable distance (fig. 7).

In this phase, the students themselves put into play the design and construction skills of the construction game, a way to test the principles of modular construction and the creation of an architectural object that is both functional and communicative.

The second phase involved visitors to the event, which started at $3 \mathrm{pm}$ and continued until after midnight. Over $40005 \times 5 \mathrm{~cm}$ cardboard cards were made available to the players, freely distributed on a series of large tables placed inside the pavilion. The boys and girls who participated were offered construction activities of different and gradual complexity: initial individual free design activities; individual construction activities using simple models made by the tutors; individual construction activities using drawings of models of different articulation; design and construction of free structures in pairs; group construction of freeform complex structures by integrating or joining existing models; in pairs, guessing in turn the identity of the model made by one's partner; finally, dismantling one's own model to allow the other players to use the cards for their own game (figs. 8, 9). 
During all the game phase, it was fundamental the contribution of tutors, students and graduates who followed the Didactics of Drawing and Graphic representations course in the academic years 2017-2018 and 2018-2019 [I]: the tutors followed the children's work stimulating them to experiment with different interlocking configurations, suggesting constructive options, enhancing the created products and managing the distribution of bricks and spaces (fig. 10).

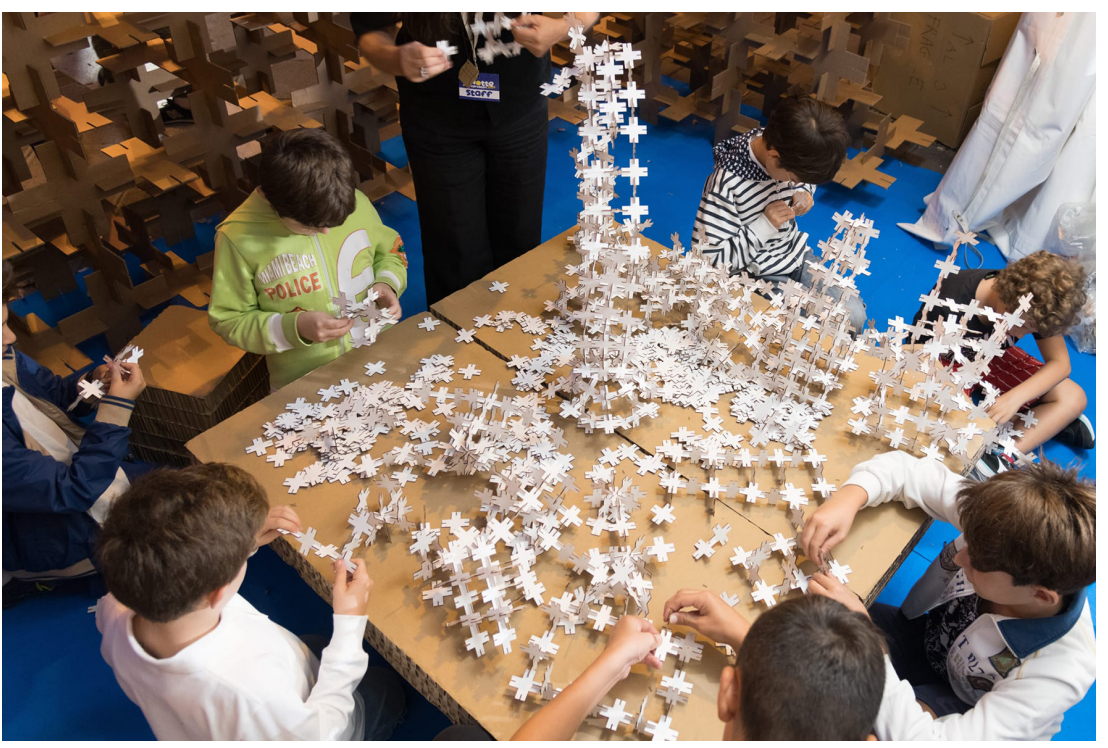

\section{Planned and achieved objectives}

Regarding the objectives of the recreational activities carried out during the Researchers' Night event, we have tried to enhance, above all, those visual-spatial and cooperative skilIs closest to the ones specific of the architect, without using pre-established models and examples to be reproduced. The aim was to make the activity as inclusive as possible, leaving users to look for personal ways of use. One of the educational objectives related to the

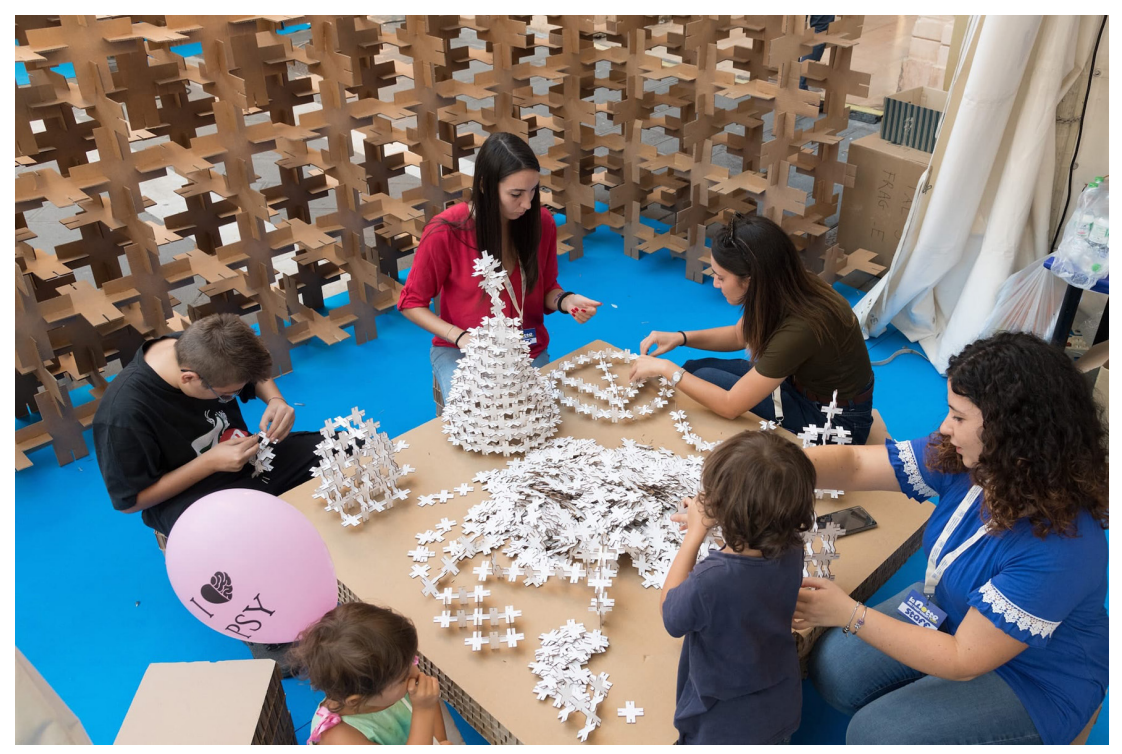


discipline of architecture that we set out to achieve, albeit in the short time spent playing, was to stimulate children to learn how to develop design hypotheses. During the game of eco-constructions, we noticed that children almost never started from a specific idea about what to build, but they always looked for different design solutions born from different combinations of assembly.

Very often, children have been caught up in the system of joints, even random ones, choosing the combinations that in their eyes, based on verisimilitude or morphological parallelisms, acquired a particular meaning. Once the subject was identified, the work of modular aggregation followed a more reasoned and rational course. Each of these design ideas can be considered as a design cluster, a sort of Purinian morpheme [Berizzi, Valeriani 2014], around which wider and more detailed hypotheses are built in a continuous path of trial and error. A mechanism that reveals an interesting parallelism with the free and creative activity

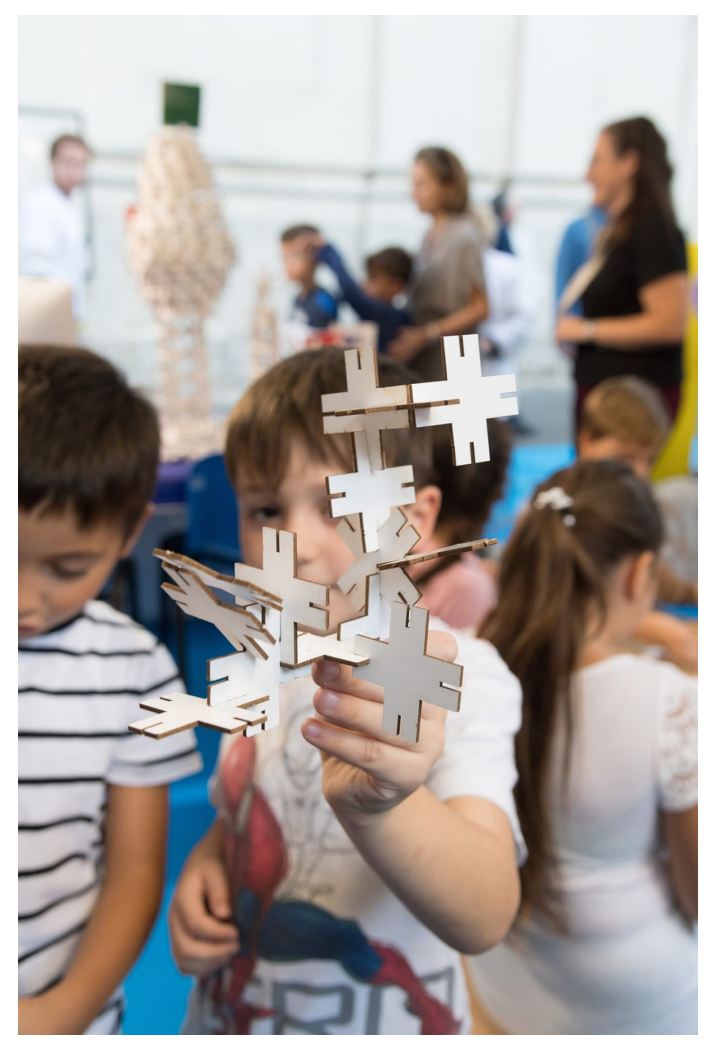

of the designers who, through the sketch, bring out new meanings and hypotheses that they refine more and more through subsequent passages (fig. II).

Through eco-bricks, other important educational objectives have also been experimented that allow to approach the principles of architecture: learning to experiment with geometrical and spatial concepts by managing the available blocks and creating three-dimensional configurations able to support themselves and not collapse by their own weight (just like in real constructions); improving the ability to connect the hand and the mind by putting together ideas, construction and aesthetics; training inventive skills by creating artifacts that have their own harmony and visible internal logic; finally, improving the ability to work on the same project by developing different social attitudes such as communicating, negotiating and sharing ideas and phases. 


\section{Conclusion}

The experience during the event of Researchers' Night 2019 was positive both for the students and teachers involved in the design and implementation of the modular eco-construction system at the two different scales, and for the numerous families and children who attended the recreational activities. The creation of the game and installation showed great potential for the creation of a sensorially rich, stimulating and inclusive space within which the meeting and dialogue between university and citizens, between researchers and ordinary people, between university students and children could take place in a fluid and natural way. The game was the privileged learning tool through which young architects were able to explore aggregation structures in space.

It was a unique and fruitful opportunity to experience in practice the transition from basic module to complex structure, from the construction bricks game to the actual architectural building in which micro and macro touch each other, within a welcoming setting in which each different voice can express itself and dialogue enriching communication and exchange of experiences, a meeting place that, like the university lecture rooms, is based on the principles of respect and cooperation.

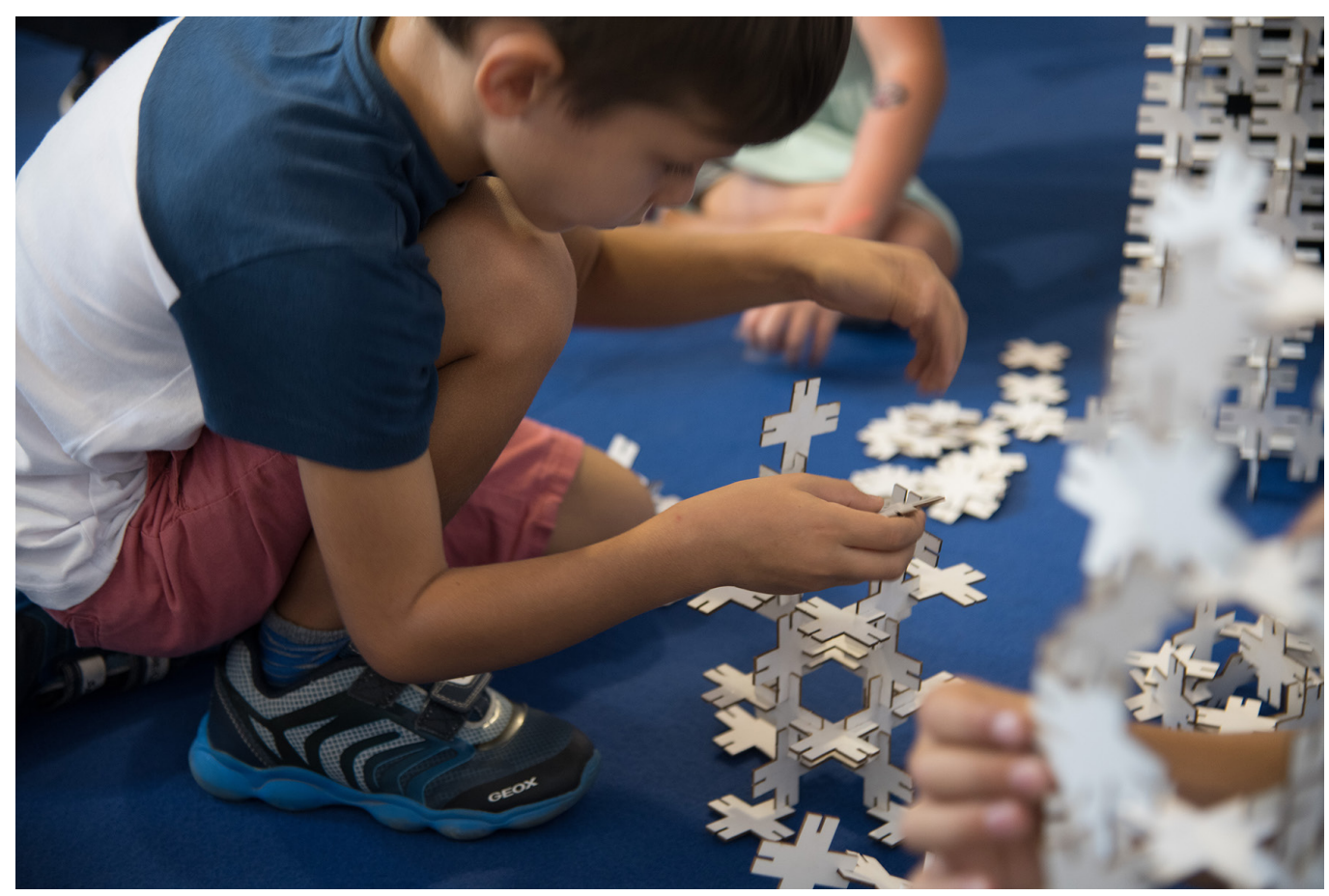

\section{Notes}

[I]Tutors and support group:Agnese Altieri, Diego Bocchini,Tonino Bucciarelli, Niccolò Cinti, Chiara Di Egidio, Noemi DiToro, Giovanna Eliantonio, Giuseppe Marino, Matteo Milinanni, Maria Luisa Pontone, Rosa Perdonò and Chiara Tuttolani.

\section{References}

Albiero Paolo et al. (200 I). Abilità di pianificazione e memoria di lavoro visuo-spaziale in soggetti di età scolare. In Età evolutiva, 68, pp. 21-33.

Anderson Peter (2002). Assessment and development of executive function during childhood. In Child Neuropsychology, 8 (2), pp. 7I-82.

Antonietti Alessandro. (1999). Can student predict when imagery will allow them to discover the problem solution? In European Journal of Cognitive Psychology, I I, pp. 407-428. 
Antonietti Alessandro, Colombo Barbara. (201 I-20I2). Mental imagery as a strategy to enhance creativity in children. In Imagination, Cognition and Personality, 31, pp. 63-77.

Berizzi Carlo,Valeriani Enrico (a cura di). (20/4). A colloquio con Franco Purini. Roma: Gangemi Editore.

Burgess PaulW. et al. (2000). The cognitive and neuroanatomical correlates of multitasking. In Neuropsychology, 38, pp. 848-863. Cornoldi Cesare (1997). Abilità visuo-spaziali: Intervento sulle difficoltà non verbali di apprendimento. Trento: Erickson.

Hanley Gerard, Levine Marvin (1983). Spatial problem solving, the integration of independently learned cognitive maps. In Memory and Cognition, II, pp. 4I5-422.

Kanizsa Gaetano (1980). Grammatica del vedere: Saggi sulla percezione e sulla Gestalt. Bologna: II Mulino.

Levine Marvin, Jankovic Irwin, Palij Michael (1982). Principles of spatial problem solving. In Journal of Experimental Psychology, I I I, pp. |57-175.

Luciana Monica, Nelson Charles A. (2002). Assessment of neuropsychological function through use of the Cambridge Neuropsychological Testing Automated Battery Performance in 4 to 12-year-old children. In Developmental Neuropsychology, 22 (3), pp. 595-624.

Maas Winy (2019). I ragazzi sono gli urbanisti di domani. In Domus, I031, 2019, pp. I0- 17.

Marcolli Attilio (1978). Teoria del campo: corso di educazione alla visione. Milano: Sansoni.

Mirri Franco (1992). La rappresentazione tecnica e progettuale: manuale di disegno per ingegneri e architetti. Roma: NIS.

Munari Bruno (1972). Design e comunicazione visiva: contributo a una metodologia didattica. Bari Laterza, 1972.

Piaget Jean, Inhelder Bärbel ( 1976). La rappresentazione dello spazio nel bambino. Firenze: Giunti Barbera.

Salmaso Luisa (20।3). Le potenzialità del gioco con i mattoncini Lego nella Scuola Primaria. In TD Tecnologie Didattiche, 2 I (3), pp. $168-174$.

Sgaramella Teresa Maria, Bisiacchi Patrizia, Falchero Roberto (2006). Ruolo dell'età nell'abilità di pianificazione di azioni in un

\section{Author}

Giovanni Caffıo, Università degli Studi “G. d'Annunzio", Chieti-Pescara, giovanni.caffio@unich.it

To cite this chapter: Caffio Giovanni (2020). +X+. Un progetto di eco-costruzioni ludiche per insegnare i principi dell'architettura modulare/ $+X+$. A project of playful eco-Bbocks to teach the principles of modular architecture. In Arena A., Arena M., Brandolino R.G., Colistra D., Ginex G., Mediati D., Nucifora S., Raffa P. (a cura di). Connettere. Un disegno per annodare e tessere. Atti del $42^{\circ}$ Convegno Internazionale dei Docenti delle Discipline della Rappresentazione/Connecting. Drawing for weaving relationships. Proceedings of the 42th International Conference of Representation Disciplines Teachers. Milano: FrancoAngeli, pp. 174-195. 